\title{
Closed Head Injury in an Age-Related Alzheimer Mouse Model Leads to an Altered Neuroinflammatory Response and Persistent Cognitive Impairment
}

\author{
Scott J. Webster, ${ }^{1}$ Linda J. Van Eldik, ${ }^{1,2,3}{ }^{-D}$ D. Martin Watterson, ${ }^{4}$ and Adam D. Bachstetter ${ }^{1}$ \\ ${ }^{1}$ Sanders-Brown Center on Aging, ${ }^{2}$ Department of Anatomy and Neurobiology, ${ }^{3}$ Spinal Cord and Brain Injury Research Center, University of Kentucky, \\ Lexington, Kentucky 40536, and ${ }^{4}$ Department of Pharmacology, Northwestern University, Chicago, Illinois 60611
}

\begin{abstract}
Epidemiological studies have associated increased risk of Alzheimer's disease (AD)-related clinical symptoms with a medical history of head injury. Currently, little is known about pathophysiology mechanisms linked to this association. Persistent neuroinflammation is one outcome observed in patients after a single head injury. Neuroinflammation is also present early in relevant brain regions during AD pathology progression. In addition, previous mechanistic studies in animal models link neuroinflammation as a contributor to neuropathology and cognitive impairment in traumatic brain injury (TBI) or AD-related models. Therefore, we explored the potential interplay of neuroinflammatory responses in TBI and $\mathrm{AD}$ by analysis of the temporal neuroinflammatory changes after TBI in an $\mathrm{AD}$ model, the APP/PS1 knock-in (KI) mouse. Discrete temporal aspects of astrocyte, cytokine, and chemokine responses in the injured KI mice were delayed compared with the injured wild-type mice, with a peak neuroinflammatory response in the injured KI mice occurring at $7 \mathrm{~d}$ after injury. The neuroinflammatory responses were more persistent in the injured KI mice, leading to a chronic neuroinflammation. At late time points after injury, KI mice exhibited a significant impairment in radial arm water maze performance compared with sham KI mice or injured wild-type mice. Intervention with a small-molecule experimental therapeutic (MW151) that selectively attenuates proinflammatory cytokine production yielded improved cognitive behavior outcomes, consistent with a link between neuroinflammatory responses and altered risk for AD-associated pathology changes with head injury.
\end{abstract}

Key words: amyloid plaque; astrocytes; cytokines; microglia; neuroinflammation; traumatic brain injury

\section{Introduction}

Approximately 1.5 million people in the United States seek emergency medical treatment annually for a traumatic brain injury (TBI) (Faul et al., 2010). Among the various TBI morbidities is an increased risk for later-in-life development of dementias, such as Alzheimer's disease (AD). For example, even a self-reported history of head injury has been found to be associated with earlier onset and increased risk of cognitive impairment and dementia (Abner et al., 2014). However, our knowledge of the pathophysiology progression attributes common to TBI and AD is limited. This knowledge could facilitate insight into the temporal progression of key pathophysiological mechanisms, thereby provid-

Received Jan. 22, 2015; revised March 10, 2015; accepted March 14, 2015.

Author contributions: S.J.W., L.J.V.E., and A.D.B. designed research; S.J.W. and A.D.B. performed research; D.M.W. contributed unpublished reagents/analytic tools; A.D.B. analyzed data; S.J.W., L.J.V.E., D.M.W., and A.D.B. wrote the paper.

This research was supported in part by National Institutes of Health/National Institute on Aging K99AG044445 to A.D.B., National Institutes of Health/National Institute of Neurological Disorders and Stroke F32 NS084605 to S.J.W., and the Kentucky Spinal Cord and Head Injury Research Trust 12-20A to L.J.V.E. We thank Danielle Goulding and Edgardo Dimayuga for assistance with various aspects of this work.

The authors declare no competing financial interests.

Correspondence should be addressed to Dr. Adam D. Bachstetter, Sanders-Brown Center on Aging, University of Kentucky, 800 S. Limestone, Lexington, KY 40536. E-mail: adam.bachstetter@uky.edu.

DOI:10.1523/JNEUROSCI.0291-15.2015

Copyright $\odot 2015$ the authors $\quad 0270-6474 / 15 / 356554-16 \$ 15.00 / 0$ ing a rational foundation to the search for new intervention strategies.

A number of TBI studies in AD-relevant animal models have documented injury effects on cognition and changes in amyloid or tau pathology (Nakagawa et al., 1999, 2000; Uryu et al., 2002; Abrahamson et al., 2006; Laskowitz et al., 2010; Schwetye et al., 2010; Tran et al., 2011; Tajiri et al., 2013; Washington et al., 2014). However, activation of microglia and astrocytes and injurious overproduction of glia products have not been studied in detail. This is a critical knowledge gap, as glia activation and upregulation of glia inflammatory mediators have been directly linked to pathophysiology progression in both TBI (Lloyd et al., 2008; Kumar and Loane, 2012; Woodcock and Morganti-Kossmann, 2013; Bachstetter et al., 2015) and AD relevant models (Bachstetter et al., 2012). Therefore, we examined the temporal profile of key neuroinflammatory responses following TBI in the context of an $\mathrm{AD}$-relevant model in which glia activation and upregulation of proinflammatory cytokine levels are linked to neurologic outcomes, including cognitive behavior. We used a closed head injury (CHI) protocol for mild TBI in an APP/PS1 knock-in (KI) mouse model of $\mathrm{AD}$ that exhibits an age-related increase in proinflammatory cytokine production and AD-related pathophysiology. We leveraged previously reported (Lloyd et al., 2008; Bachstetter et al., 2012) time courses of the pathophysiology endpoint changes in either TBI or the KI model to focus our analysis 
on $9 \mathrm{~h}, 1 \mathrm{~d}, 7 \mathrm{~d}, 1$ month, and 2 month time points after $\mathrm{CHI}$ in the KI mouse.

We found that a single mild TBI in the KI mouse led to a delayed onset of neuroinflammatory responses and a more persistent glia activation compared with injured wild-type (WT) mice. In addition, $\mathrm{CHI}$ in the $\mathrm{KI}$ mouse induced chronic behavioral impairments that did not resolve even at the 2 month time point. We explored mechanistic linkage among the correlative findings by using intervention with MW151, an experimental anti-neuroinflammatory drug that restores excessive proinflammatory cytokine production back toward normal with a resultant improvement in neurologic outcomes in either TBI or AD mouse models. We found that MW151 treatment of KI mice subjected to $\mathrm{CHI}$ prevented cognitive impairment when given during the period of heightened neuroinflammation. Overall, our data support the hypothesis that TBI in the context of AD susceptibility can lead potentially to greater cognitive impairment via mechanisms that involve glia neuroinflammatory responses.

\section{Materials and Methods}

Mice. The Institutional Animal Care and Use Committee of the University of Kentucky approved all procedures, which were conducted in accordance with the principles of animal care and experimentation in the Guide for the Care and Use of Laboratory Animals. The mouse model $\mathrm{APP}^{\mathrm{NLh} / \mathrm{NLh}} \times \mathrm{PS}^{\mathrm{P} 264 \mathrm{~L} / \mathrm{P} 264 \mathrm{~L}}$ (APP/PS1 KI) was developed (Flood et al., 2002) and characterized as previously described (Webster et al., 2013). Experiments used both male and female mice at 50/50 ratio where possible. Mice were randomized to assigned groups before the start of the experiments.

Surgical procedure. The CHI surgical procedures were as previously described (Lynch et al., 2005; Lloyd et al., 2008) with slight modification. Mice were anesthetized with $5 \%$ isoflurane before stabilizing the head using ear bars in a digital mouse stereotaxic frame (Stoelting). Anesthesia was maintained with continuous inhalation of isoflurane $(3.5 \%, 1$ $\mathrm{L} / \mathrm{min}$ ).

A midline sagittal scalp incision was made. A $1 \mathrm{ml}$ latex pipette bulb (Fisher Scientific) was placed under the head and filled with water to displace the force of the impact. Any animal with damage to the ear from the ear bars, resulting in rolling or bleeding, was eliminated. The stereotaxic electromagnetic impactor (Brody et al., 2007) with a $5.0 \mathrm{~mm}$ steel tip impounder (Leica Biosytems) was used to deliver a single controlled midline cortical impact, delivered (at coordinates: mediolateral, $0.0 \mathrm{~mm}$; anteroposterior, $-1.5 \mathrm{~mm}$ ) with a controlled velocity $(5.0 \pm 0.2 \mathrm{~m} / \mathrm{s})$, dwell time $(100 \mathrm{~ms})$, and impact depth $(1.0 \mathrm{~mm})$. Mice with depressed skull fracture or visible hemorrhage were excluded from the study. Sham-injured mice underwent identical surgical procedures as the trauma group, but no impact was delivered. The time elapsed until the animal spontaneously rights was recorded as an acute neurological assessment and defined as the righting reflex time. For our mild injury model, the mortality rate for brain-injured rodents during our last 500 CHI surgeries was $1.4 \%$ of the animals dying as a result of the injury within the acute post-traumatic period. We have found that in young mice ( $3-5$ months old), the mortality rate is $\sim 0.9 \%$, whereas in this study with older mice ( 8 months old at time of $\mathrm{CHI}$ ), the mortality rates were slightly higher (2.3\% for KI mice, $2.7 \%$ for WT mice). Following each surgery, animals were visually monitored every $10 \mathrm{~min}$ to ensure safe recovery.

Nesting behavior. The nesting followed established protocols (Deacon, 2006, 2012) as previously described (Bachstetter et al., 2013a). Briefly, nesting was measured in four separate cohorts of mice (cohorts 2-5) at four different time points after injury as indicated in Figure 1a. A nestlet consisting of a $5 \mathrm{~cm} \times 5 \mathrm{~cm}$ pressed cotton square (Ancare, UK agent, Lillico) was added to the cage between 5:00 PM and 6:00 PM. The following morning between 9:00 AM and 10:00 AM, two observers blind to the experimental conditions scored the quality of the nest following a semiquantitative 5 -point scale $(1,>90 \%$ of nestlet intact; $2,50 \%-90 \%$ of nestlet intact; $3,10 \%-50 \%$ of nestlet intact but no identifiable nest site; 4 ,
$<10 \%$ of nestlet intact, nest is identifiable but flat; $5,<10 \%$ of nestlet intact, nest is identifiable with walls higher than the mouse body).

Running wheel behavior. Running wheel apparatuses were purchased from Lafayette Instruments, and the chambers were $35.3 \mathrm{~cm} \times 23.5$ $\mathrm{cm} \times 20 \mathrm{~cm}$ (length $\times$ width $\times$ height). The running wheel component itself was made out of stainless steel and consisted of a wheel of $12.7 \mathrm{~cm}$ diameter $\times 5.72 \mathrm{~cm}$ width with 38 uniformly spaced rungs for the mice to run on. At 12-14 h following the $\mathrm{CHI}$ or sham injury, the mice were introduced into the running wheels and data were recorded for $5 \mathrm{~d}$ of recovery. Computerized counting software (Lafayette Instruments) automatically recorded the total distance run each hour by each animal, and then these $1 \mathrm{~h}$ blocks were combined into $24 \mathrm{~h}$ ( $1 \mathrm{~d}$ ) blocks to be presented graphically.

Radial arm water maze (RAWM) behavior. The RAWM followed the well-established $2 \mathrm{~d}$ protocol (Alamed et al., 2006), as previously described (Webster et al., 2013). Briefly, in block 1 (first 6 trials) and block 2 ( 6 trials), mice were trained to identify the platform location by alternating between a visible and a hidden platform ( 3 hidden platform trials and 3 visible platform trials for each block). Block 3 ( 3 trials) used only a hidden platform. The next day, mice were tested in 3 blocks of 5 trials each (blocks 4-6; 15 total trials), all using only a hidden platform to test their spatial memory retention. Data are presented as the average errors per block during the hidden platform trials. RAWM performance was recorded and scored using EthoVision XT 8.0 video tracking software (Noldus Information Technology). Behavioral data for both genders were combined after observing no differences between the behavioral responses of male and female mice tested.

Brain tissue harvesting, biochemical and immunohistochemical (IHC) endpoints. Mice were deep anesthetized with 5\% isoflurane before transcardial perfusion with ice-cold PBS for $5 \mathrm{~min}$. The brains were rapidly removed, dissected, processed, and archived for subsequent biochemical and IHC endpoints as previously described (Bachstetter et al., 2012). Brain homogenates for cytokine and $\mathrm{A} \beta$ protein levels were made as previously described (Bachstetter et al., 2012). Levels of IL- $\beta$, TNF $\alpha$, and $\mathrm{A} \beta 1-40$ and $\mathrm{A} \beta 1-42$ were measured by V-Plex ELISA from Meso Scale Discovery (MSD) according to the manufacturer's instructions as we have previously described (Bachstetter et al., 2012). Gene expression was measured by real-time PCR, using the TaqMan Gene Expression Assay Kit (Applied Biosystems, catalog \#4444964) according to the manufacturer's instructions on a ViiA 7 Real-Time PCR System (Applied Biosystems). Relative gene expression was calculated by the $2^{-\Delta \Delta C T}$ method as previously described (Bachstetter et al., 2013b). IHC staining was done following established methods (Bachstetter et al., 2012, 2013b). Primary antibodies used included the following: rabbit anti-GFAP (Dako, catalog \#Z0334; 1:10,000); rabbit anti-IBA1 (Wako, catalog \#019-19741; 1:10,000); mouse anti-A $\beta$ 6E10 (Covance, catalog \#SIG-39340, 1:3000) monoclonal antibody; and rabbit anti-A $\beta 1-42$ (Invitrogen, catalog $\# 44344,1: 750$ ). Quantitative image analysis of IHC was conducted as previously described (Bachstetter et al., 2012, 2013b). Briefly, Aperio ScanScope XT digital slide scanner was used to image the entire stained slide at $20 \times$ magnification to create a single high-resolution digital image. The cortex was outlined using the Aperio ImageScope software. The Aperio-positive pixel count algorithm (version 9) was used to quantify the amount of specific staining in the region. The number of positive pixels was normalized to the number of total pixels (positive and negative) to account for variations in the size of the region sampled. The resulting color markup of the analysis was confirmed for each slide. Personnel blind to the experimental conditions performed all quantifications.

Synthesis and use of MW151. MW01-2-151SRM (2-(4-(4-methyl-6phenylpyridazin-3 yl)piperazin-1-yl)pyrimidine) was synthesized and characterized as previously reported (Hu et al., 2007). MW151 is a watersoluble, chemically stable, small molecule (423 MW) that is orally bioavailable and CNS-penetrant, with a brain-blood ratio $>1$, similar to other CNS drugs in clinical use or under development. MW151 is not a pan-suppressor of neuroinflammation; for example, MW151 suppresses injury- or disease-induced upregulation of proinflammatory cytokines, such as IL- $1 \beta$ and TNF $\alpha$, but does not block anti-inflammatory cytokines, such as IL-10 (Bachstetter et al., 2012, 2015). MW151 efficacy is 
achieved in the absence of any signs of general immunosuppression or nonselective anti-inflammatory action, as documented in diverse animal models (Hu et al., 2007; Somera-Molina et al., 2007, 2009; Karpus et al., 2008; Lloyd et al., 2008; Chrzaszcz et al., 2010; Bachstetter et al., 2012, 2015; Jenrow et al., 2013; Macauley et al., 2014). MW151 was administered as previously described (Bachstetter et al., 2012). MW151 was dissolved in $0.9 \%$ sterile $\mathrm{NaCl}$ (saline: Hospira NDC 0409-4888-10), and administered by intraperitoneal injection. Saline was injected intraperitoneally as the vehicle control.

Statistics. JMP Software version 10.0 was used for statistical analysis. A repeated-measures ANOVA was used for running wheel behavior and RAWM. For all other endpoints, a two-way ANOVA was used comparing injury groups, time after injury, and their interaction as factors. If a significant main effect of injury group, or time after injury was found, then a one-way ANOVA was used to examine differences within those factors. A two-tailed Student's $t$ test was used for post hoc analysis to compare only the effect of injury in the WT and KI mice, and effect of genotype (WT vs $\mathrm{KI}$ ) in response to $\mathrm{CHI}$, as these comparisons were determined a priori to be the ones of interest. The $F$ values are shown in Tables 1, 2, and 3 for the one- and two-way ANOVA, along with the $p$ values for the ANOVAs and T tests. Differences between mean were considered significant at $\alpha=0.05$. Graphs were generated using GraphPad Prism software version 6.0. Values are expressed as mean \pm SEM.

\section{Results}

\section{Rationale and animal model systems}

The overall goal of this study was to use $\mathrm{CHI}$ in an $\mathrm{AD}$ mouse model to probe whether TBI would alter or possibly accelerate AD-relevant pathophysiology changes, especially cognitive deficits that define $\mathrm{AD}$ and related dementias, to identify a potential mechanism amenable to modulation by intervention. The $\mathrm{AD}$ mouse model we used is the APP ${ }^{\text {NLh/NLh }} \times \mathrm{PS}^{\mathrm{P} 264 \mathrm{~L} / \mathrm{P} 264 \mathrm{~L}}$ double gene-targeted knock-in (APP/PS1 KI) mouse (Flood et al., 2002). Gene expression in this humanized KI mouse model is driven by endogenous promoters of the amyloid precursor protein (APP) and presenilin-1 (PS1) genes, and the APP and PS1 genes contain selective point mutations linked to familial AD (Reaume et al., 1996; Siman et al., 2000; Flood et al., 2002). The APP/PS1 KI mouse is particularly advantageous in that it preserves physiologically relevant APP expression levels and demonstrates progressive and age-related AD pathology without APP overproduction (Murphy et al., 2007). Critical to this study, the temporal changes in proinflammatory cytokine upregulation are known, and their link to disease-relevant neurologic outcomes, such as synaptic dysfunction, established through intervention with the experimental therapeutic MW151, a selective attenuator of stressrelated proinflammatory overproduction (Bachstetter et al., 2012). Separate but parallel observations have been made with TBI in mouse models. Briefly, CHI induces proinflammatory cytokine increases that can be attenuated by MW151 intervention within the appropriate dosing time window, with a resultant improvement in cognitive behavior (Lloyd et al., 2008).

Among the diverse rodent TBI protocols available (Xiong et al., 2013), we chose a midline CHI protocol that uses an electromagnetic impactor and is characterized by the following features: (1) a mild injury, (2) primarily diffuse, (3) no cortical contusions or gross tissue loss, (4) no craniotomy required, (5) reproducible, and (6) low mortality. The injury produces a transient apparent loss of consciousness $\sim 7-8 \mathrm{~min}$ in length with no significant difference in righting reflex between the $\mathrm{WT}+\mathrm{CHI}$ group $(\sim 7$ $\min \pm 41.1 \mathrm{~s}$; mean $\pm \mathrm{SEM})$ and the $\mathrm{KI}+\mathrm{CHI}$ group $(\sim 8 \mathrm{~min} \pm$ $41.3 \mathrm{~s}$; mean $\pm \mathrm{SEM}$ ). Similarly, mortality rates were not significantly different between WT (2.7\%) and KI (2.3\%). Less than $1 \%$ of mice were excluded for skull fractures or ear problems from the surgical procedure.

\section{Injured APP/PS1 KI mice show persistent behavioral deficits} The initial tests for CHI outcomes were for behavior using the study design outlined in Figure 1a. Two nonforced behavioral measures of activity were used: a home cage running wheel (Fig. $1 b$ ) and nesting behavior (Fig. 1c). A cohort of mice (Fig. 1a, cohort 3) was allowed access in the home cage to a running wheel for $5 \mathrm{~d}$ after the $\mathrm{CHI}$ or sham surgery. Deficits in the running wheel during the first $3 \mathrm{~d}$ post-injury (p.i.) self-attenuate and reach baseline $\sim 5 \mathrm{~d}$. As shown in Figure $1 b$, the $\mathrm{CHI}$-induced deficit in the distance traveled is evident in both the WT and KI mice. Using a repeated-measures ANOVA, we found a significant effect of injury $(p=0.0149)$, but no effect of genotype.

We also measured nesting behavior as another test of activity. Nest building is a naturalistic mouse behavior similar to an "activity of daily living," which is related to thermoregulation, exploration, and camouflage (Deacon, 2006, 2012). Cohorts 2-5 were tested at $1 \mathrm{~d}, 7 \mathrm{~d}, 1$ month, and 2 months p.i. for the ability to make a nest. As shown in Figure $1 c$, at $1 \mathrm{~d}$ following injury, both WT and KI mice made nests of significantly lower quality compared with the respective sham-injured controls (WT, $p=$ 0.0028 ; KI, $p=0.0025)$. At $7 \mathrm{~d}$ p.i, the WT mice no longer showed a significant effect of injury, but the $\mathrm{KI}+\mathrm{CHI}$ mice continued to make a significantly lower-quality nest than the sham-injured KI mice $(p=0.0005)$. By 1 month p.i., the WT mice were fully recovered in nesting behavior, whereas the $\mathrm{KI}+\mathrm{CHI}$ mice continued to show a significant deficit in nest building ability ( $p=$ 0.0232). Remarkably, even at 2 months p.i., the KI+CHI mice still showed a significant deficit in the ability to make a nest ( $p=$ $0.0061)$.

A prototypical behavioral outcome of $\mathrm{CHI}$ in mice is cognitive impairment, generally measured by RAWM or Morris water maze deficits. To determine whether APP/PS1 KI mice had increased susceptibility to develop cognitive deficits following a single CHI, we injured mice at 8 months of age and measured cognitive changes by RAWM at 9 months of age (Fig. 1a). The rationale for choosing these ages is that, at $8-9$ months of age, the KI mice exhibit some (but not extensive) amyloid deposition (Flood et al., 2002; Murphy et al., 2007; Zhang et al., 2007), but no cognitive deficits in the RAWM until 11 months of age (Webster et al., 2013). Therefore, this paradigm allowed us to inflict a TBI in an environment of amyloid pathology and test the KI mice in the RAWM before cognitive impairments are normally evident.

We hypothesized that $\mathrm{CHI}$ would exaggerate the cognitive impairment in the APP/PS1 KI mice. Prior studies using a moderate-to-severe controlled cortical impact TBI model in PDAPP or Tg2576 mice have shown that the injured transgenic mice have a worse outcome in Morris water maze or RAWM compared with the injured WT mice (Brody and Holtzman, 2006; Tajiri et al., 2013). In a lateral CHI in Tg2576 mice, repetitive CHIs were required to induce a Morris water maze deficit, as one CHI was not sufficient; however, even repetitive CHIs in WT mice did not induce a cognitive deficit (Uryu et al., 2002). Thus, a threshold of injury severity may be necessary to induce cognitive impairment. Therefore, we tested whether the mild diffuse injury associated with our CHI model would be sufficient to overcome that threshold. We previously found deficits in RAWM performance at $14 \mathrm{~d}$ p.i. in WT mice (Bachstetter et al., 2015). As shown in Figure $1 d$, by 1 month p.i. in WT + CHI mice, the deficit in RAWM performance has resolved and the injured mice are not different from the sham group. However, at this time point, the $\mathrm{KI}+\mathrm{CHI}$ mice still exhibited a significant cognitive impairment. Using a repeated-measures ANOVA, we found a significant effect of training $(p<0.0001)$ and treatment group $(p=0.0008)$. Post 
Table 1. Summary of statistics for cytokines and chemokines following $\mathrm{CHI}^{a}$

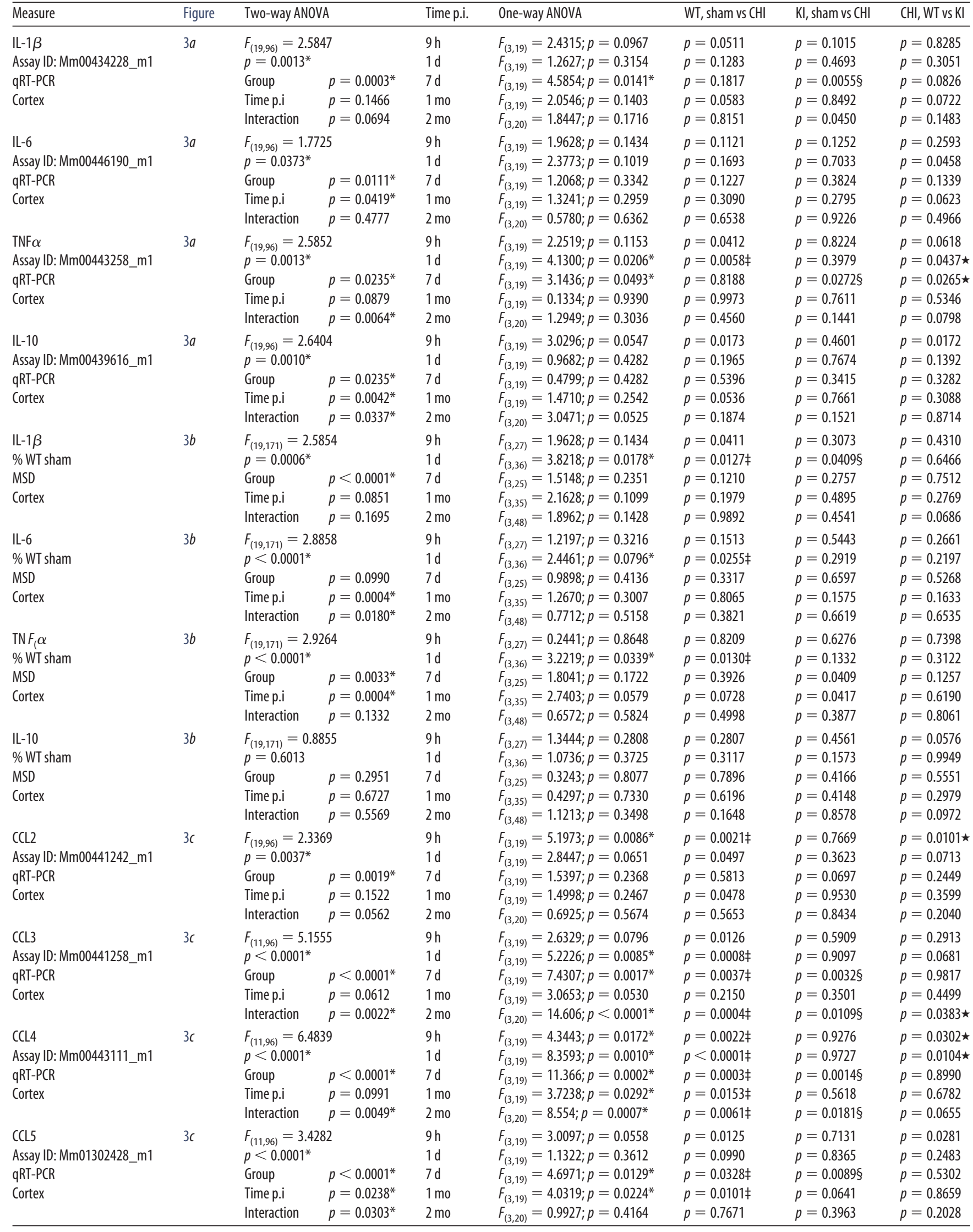


Table 2. Summary of statistics for microglia following $\mathrm{CHI}^{a}$

\begin{tabular}{|c|c|c|c|c|c|c|c|c|}
\hline Measure & Figure & \multicolumn{2}{|c|}{ Two-way ANOVA } & Time p.i. & One-way ANOVA & WT, sham vs CHI & $\mathrm{Kl}$, sham vs $\mathrm{CHI}$ & CHI, WT vs KI \\
\hline IBA1 & \multirow[t]{5}{*}{$4 c$} & \multirow{2}{*}{\multicolumn{2}{|c|}{$\begin{array}{l}F_{(11,86)}=4.4416 \\
D<0.0001^{*}\end{array}$}} & $9 \mathrm{~h}$ & & & & \\
\hline $\mathrm{IHC}$ & & & & $1 d$ & $F_{(3,20)}=3.4323 ; p=0.0367^{*}$ & $p=0.0071 \ddagger$ & $p=0.2629$ & $p=0.5042$ \\
\hline \multirow[t]{3}{*}{ Positive pixels cortex } & & Group & $p=0.004^{*}$ & $7 d$ & $F_{(3,24)}=3.0262 ; p=0.0491^{*}$ & $p=0.0332 \ddagger$ & $p=0.0306 \S$ & $p=0.5933$ \\
\hline & & Time p.i & $p=0.1715$ & $1 \mathrm{mo}$ & & & & \\
\hline & & Interaction & $p=0.0070^{*}$ & $2 \mathrm{mo}$ & $F_{(3,42)}=7.4269 ; p=0.0004^{*}$ & $p=0.3316$ & $p=0.8538$ & $p=0.0129 \star$ \\
\hline CX3CR1 & \multirow[t]{5}{*}{$4 c$} & \multirow{2}{*}{\multicolumn{2}{|c|}{$\begin{array}{l}F_{(19,96)}=1.2676 \\
p=0.2234\end{array}$}} & $9 \mathrm{~h}$ & $F_{(3,19)}=0.1864 ; p=0.9043$ & $p=0.7775$ & $p=0.9694$ & $p=0.5324$ \\
\hline Assay ID:Mm02620111_s1 & & & & $1 d$ & $F_{(3,19)}=0.1802 ; p=0.9085$ & $p=0.2929$ & $p=0.9347$ & $p=0.6569$ \\
\hline qRT-PCR & & Group & $p=0.2030$ & $7 \mathrm{~d}$ & $F_{(3,19)}=0.6103 ; p=0.6165$ & $p=0.5164$ & $p=0.9347$ & $p=0.5818$ \\
\hline \multirow[t]{2}{*}{ Cortex } & & Time p.i & $p=0.0107^{*}$ & $1 \mathrm{mo}$ & $F_{(3,19)}=0.8656 ; p=0.4760$ & $p=0.1947$ & $p=0.9189$ & $p=0.8573$ \\
\hline & & Interaction & $p=0.9458$ & $2 \mathrm{mo}$ & $F_{(3,20)}=1.0179 ; p=4056$ & $p=0.9625$ & $p=0.2173$ & $p=0.1603$ \\
\hline CCR2 & \multirow[t]{5}{*}{$4 c$} & $F_{(19,96)}=1$ & & $9 \mathrm{~h}$ & $F_{(3,19)}=0.9515 ; p=0.4356$ & $p=0.9501$ & $p=0.6583$ & $p=0.1711$ \\
\hline Assay ID:Mm00438270_m1 & & $p=0.0233$ & & $1 d$ & $F_{(3,19)}=0.3820 ; p=0.7671$ & $p=0.8676$ & $p=0.3102$ & $p=0.5965$ \\
\hline qRT-PCR & & Group & $p=0.1590$ & $7 d$ & $F_{(3,19)}=0.8827 ; p=0.4677$ & $p=0.1961$ & $p=0.7296$ & $p=0.8286$ \\
\hline \multirow[t]{2}{*}{ Cortex } & & Time p.i & $p=0.0610$ & $1 \mathrm{mo}$ & $F_{(3,19)}=1.7086 ; p=0.1991$ & $p=0.9751$ & $p=0.0699$ & $p=0.1083$ \\
\hline & & Interaction & $p=0.0769$ & $2 \mathrm{mo}$ & $F_{(3,20)}^{(3,1)}=0.9666 ; p=0.4279$ & $p=0.3124$ & $p=0.9882$ & $p=0.6720$ \\
\hline CD68 & \multirow[t]{5}{*}{$4 c$} & $F_{(19,96)}=2$ & & $9 \mathrm{~h}$ & $F_{(3,19)}=2.5462 ; p=0.0865$ & $p=0.0411$ & $p=0.1768$ & $p=0.2849$ \\
\hline Assay ID:Mm00839636_g1 & & $p=0.0033$ & & $1 d$ & $F_{(3,19)}=1.2658 ; p=0.3144$ & $p=0.0836$ & $p=0.8098$ & $p=0.2244$ \\
\hline qRT-PCR & & Group & $p=0.0007^{*}$ & $7 d$ & $F_{(3,19)}=4.5303 ; p=0.0147^{*}$ & $p=0.0405 \ddagger$ & $p=0.0333 \S$ & $p=0.1941$ \\
\hline \multirow[t]{2}{*}{ Cortex } & & Time p.i & $p=0.0091^{*}$ & $1 \mathrm{mo}$ & $F_{(3,19)}=0.7271 ; p=0.5483$ & $p=0.2061$ & $p=0.7607$ & $p=0.7394$ \\
\hline & & Interaction & $p=0.4712$ & $2 \mathrm{mo}$ & $F_{(3,20)}=0.9680 ; p=0.4273$ & $p=0.1235$ & $p=0.6449$ & $p=0.4371$ \\
\hline MHCII & \multirow[t]{5}{*}{$4 c$} & $F_{(19,96)}=0$ & & $9 \mathrm{~h}$ & $F_{(3,19)}^{(3,20)}=1.0969 ; p=0.3747$ & $p=0.2963$ & $p=0.8076$ & $p=0.7030$ \\
\hline Assay ID:Mm00439216_m1 & & $p=0.4854$ & & $1 d$ & $F_{(3,19)}=0.3209 ; p=0.8102$ & $p=0.9197$ & $p=0.9758$ & $p=0.5301$ \\
\hline qRT-PCR & & Group & $p=0.3485$ & $7 d$ & $F_{(3,19)}=0.9623 ; p=0.4308$ & $p=0.9468$ & $p=0.1823$ & $p=0.1763$ \\
\hline \multirow[t]{2}{*}{ Cortex } & & Time p.i & $p=0.4557$ & $1 \mathrm{mo}$ & $F_{(3,19)}=1.7895 ; p=0.1833$ & $p=0.0446$ & $p=0.4158$ & $p=0.6600$ \\
\hline & & Interaction & $p=0.5043$ & $2 \mathrm{mo}$ & $F_{(3,20)}=1.1880 ; p=0.3395^{*}$ & $p=0.2225$ & $p=0.1803$ & $p=0.9253$ \\
\hline
\end{tabular}

$a_{*}^{*}$ Denotes significant effect by ANOVA.

‡Denotes significant difference between WT + sham vs. WT + CHI.

§Denotes significant difference between $\mathrm{KI}+$ sham vs. $\mathrm{KI}+\mathrm{CHI}$.

$\star$ Denotes significant difference between WT + CHI vs. KI + CHI.

Table 3. Summary of statistics for astrocytes following $\mathrm{CHI}^{a}$

\begin{tabular}{|c|c|c|c|c|c|c|c|c|}
\hline Measure & Figure & \multicolumn{2}{|c|}{ Two-way ANOVA } & Time p.i. & One-way ANOVA & WT, sham vs CHI & $\mathrm{Kl}$, sham vs $\mathrm{CHI}$ & CHI, WT vs KI \\
\hline GFAP & \multirow[t]{4}{*}{$5 b$} & \multicolumn{2}{|c|}{$F_{(11,125)}=19.58$} & $9 \mathrm{~h}$ & & & & \\
\hline $\mathrm{IHC}$ & & \multicolumn{2}{|c|}{$p<0.0001^{*}$} & $1 d$ & $F_{(3,48)}=3.7256 ; p=0.0178^{*}$ & $p=0.2866$ & $p=0.0288 \S$ & $p=0.0442 \star$ \\
\hline \multirow[t]{2}{*}{ Positive pixels cortex } & & Group & $p<0.0001^{*}$ & $7 d$ & $F_{(3,29)}=2.1772 ; p=0.1148$ & $p=0.0556$ & $p=0.2766$ & $p=0.7578$ \\
\hline & & Interaction & $p<0.0001^{*}$ & $2 \mathrm{mo}$ & $F_{(3,46)}=31.194 ; p<0.0001^{*}$ & $p=0.2780$ & $p<0.0001 \S$ & $p<0.0001 \star$ \\
\hline GFAP & \multirow[t]{3}{*}{$5 c$} & \multirow{2}{*}{\multicolumn{2}{|c|}{$\begin{array}{l}F_{(19,96)}=3.1755 \\
p<0.0001^{*}\end{array}$}} & $9 \mathrm{~h}$ & $F_{(3,19)}=7.6226 ; p=0.0015^{*}$ & $p=0.0013 \ddagger$ & $p=0.3182$ & $p=0.0030 \star$ \\
\hline Assay ID:Mm00546086_m1 & & & & $1 d$ & $F_{(3,19)}=4.2435 ; p=0.0187^{*}$ & $p=0.0026 \ddagger$ & $p=0.8257$ & $p=0.0372 \star$ \\
\hline Cortex & & Interaction & $p=0.0748$ & $2 \mathrm{mo}$ & $F_{(3,20)}=6.4318 ; p=0.0032^{*}$ & $p=0.0209 \ddagger$ & $p=0.0138 \S$ & $p=0.0892$ \\
\hline VIM & \multirow[t]{4}{*}{$5 c$} & \multirow{2}{*}{\multicolumn{2}{|c|}{$\begin{array}{l}F_{(19,96)}=3.1755 \\
p<0.0001^{*}\end{array}$}} & $9 \mathrm{~h}$ & $F_{(3,19)}=7.6226 ; p=0.0015^{*}$ & $p=0.0013 \ddagger$ & $p=0.3182$ & $p=0.0030 \star$ \\
\hline Assay ID:Mm01333430_m1 & & & & $1 d$ & $F_{(3,19)}=4.2435 ; p=0.0187^{*}$ & $p=0.0026 \neq$ & $p=0.8257$ & $p=0.0372 \star$ \\
\hline qRT-PCR & & Group & $p=0.0001^{*}$ & $7 d$ & $F_{(3,19)}=3.7997 ; p=0.0274^{*}$ & $p=0.0712$ & $p=0.0172 \S$ & $p=0.3362$ \\
\hline Cortex & & Time p.i & $p=0.0497^{*}$ & $1 \mathrm{mo}$ & $F_{(3,19)}^{(3,1)}=0.4212 ; p=0.7399$ & $p=0.3213$ & $p=0.6454$ & $p=0.4431$ \\
\hline \multirow[t]{2}{*}{ Cortex } & \multirow{2}{*}{$5 c$} & Time p.i & $p=0.2770$ & $1 \mathrm{mo}$ & $F_{(3,19)}^{(3,1)}=1.7664 ; p=0.1877$ & $p=0.3996$ & $p=0.5499$ & $p=0.4542$ \\
\hline & & Interaction & $p=0.0083^{*}$ & $2 \mathrm{mo}$ & $F_{(3,20)}=3.8335 ; p=0.0256^{*}$ & $p=0.1279$ & $p=0.0113 \S$ & $p=0.1855$ \\
\hline PTX3 & \multirow[t]{5}{*}{$5 c$} & \multirow{2}{*}{\multicolumn{2}{|c|}{$\begin{array}{l}F_{(19,96)}=3.9352 \\
p<0.0001^{*}\end{array}$}} & $9 \mathrm{~h}$ & $F_{(3,19)}=6.3087 ; p=0.0038^{*}$ & $p=0.0019 \ddagger$ & $p=0.4054$ & $p=0.0067 \star$ \\
\hline Assay ID:Mm00477268_m1 & & & & $1 d$ & $F_{(3,19)}=3.0603 ; p=0.0532$ & $p=0.0228$ & $p=0.9488$ & $p=0.0204$ \\
\hline qRT-PCR & & Group & $p<0.0001^{*}$ & $7 d$ & $F_{(3,19)}=3.2649 ; p=0.0441^{*}$ & $p=0.3084$ & $p=0.0324 \S$ & $p=0.0720$ \\
\hline \multirow[t]{2}{*}{ Cortex } & & Time p.i & $p=0.0971$ & $1 \mathrm{mo}$ & $F_{(3,19)}=0.0956 ; p=0.9615$ & $p=0.6657$ & $p=0.9579$ & $p=0.7624$ \\
\hline & & Interaction & $p=0.0006^{*}$ & $2 \mathrm{mo}$ & $F_{(3,20)}=2.9249 ; p=0.0589$ & $p=0.1966$ & $p=0.0331$ & $p=0.1733$ \\
\hline
\end{tabular}




\section{a study design}

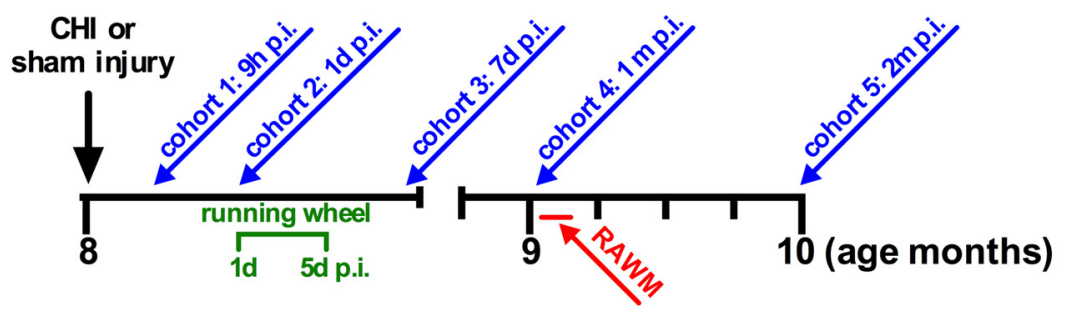

b running wheel

c nesting

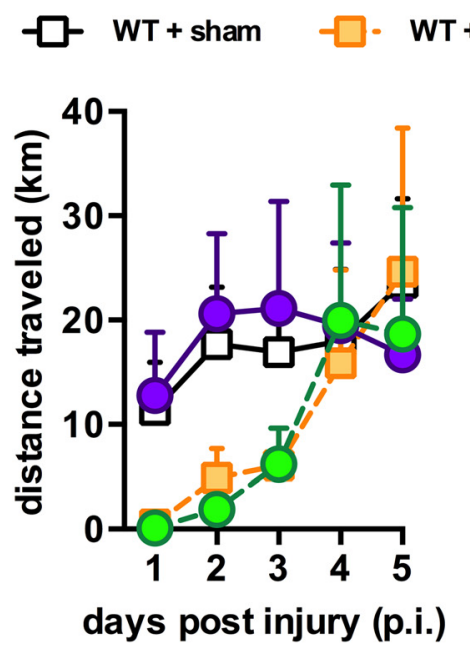

d RAWM at $1 \mathrm{mos}$ p.i.
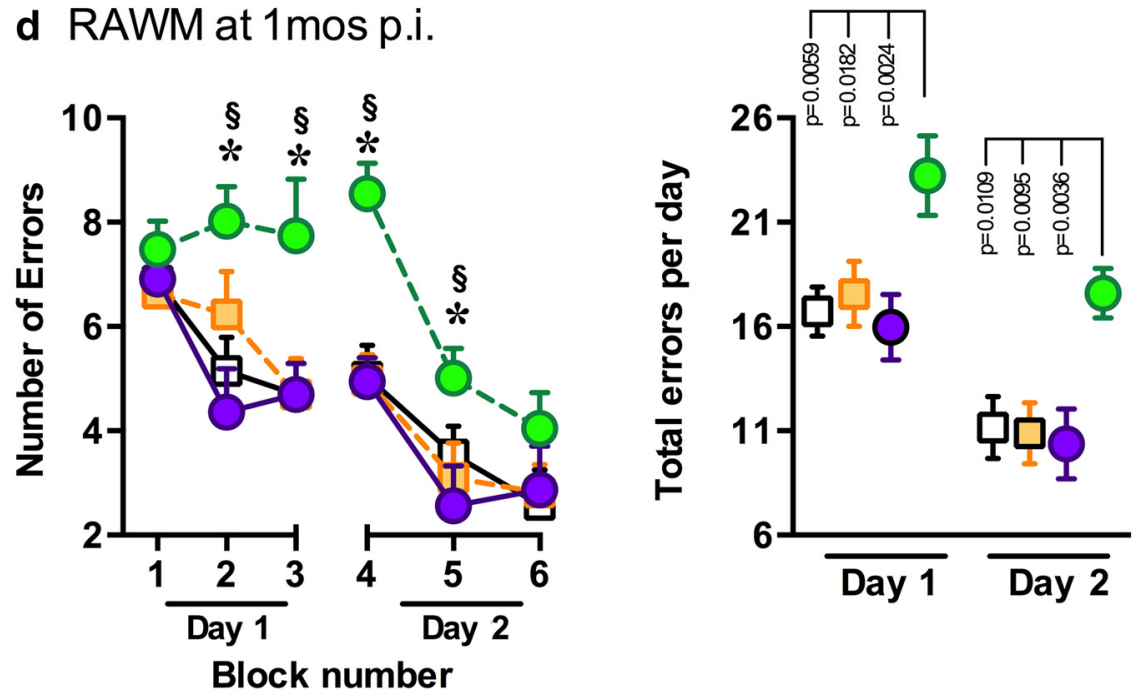

Figure 1. Injured APP/PS1 KI mice show persistent behavioral impairments. $\boldsymbol{a}$, Overview of study design and experimental groups. WT and KI mice (8 months old) were subjected to CHI or sham injury, and different cohorts examined at $9 \mathrm{~h}, 1 \mathrm{~d}, 7 \mathrm{~d}, 1$ month, and 2 months p.i. $\boldsymbol{b}$, Cohort 3 was tested for running wheel activity on p.i. days $1-5$. CHI caused a transient reduction in spontaneous running wheel activity that was similar in both WT and KI mice ( $n=7$ or 8 per group). c, Cohorts $2-5$ were tested at $1 \mathrm{~d}, 7 \mathrm{~d}, 1$ month, and 2 months p.i. for the ability to make a nest. Following $\mathrm{CHI}$, both WT and KI mice made lower-quality nests at $1 \mathrm{~d}$ after the injury. However, WT mice recovered normal nesting behavior by $7 \mathrm{~d}$ to 1 month $\mathrm{p}$.i., whereas the KI mice continued to have a significant deficit even at 2 months p.i. $\neq p<0.05 \mathrm{WT}+$ sham versus WT $+\mathrm{CHI} .{ }^{*} p<0.05 \mathrm{KI}+$ sham versus $\mathrm{KI}+\mathrm{CHI}(n=$ 7-22 per group).d, Cohort 5 was tested in the RAWM at 9 months of age (1 month p.i.). At this time point, the injury-induced deficit in cognitive performance in WT mice had resolved, but the injured KI mice remained significantly impaired compared with the other groups ( $n=10-14$ per group). *Denotes significant difference between WT + CHI vs. KI + CHI. $\neq$ Denotes significant difference between WT + sham vs. WT + CHI. §Denotes significant difference between $\mathrm{KI}+$ sham vs. KI + CHI. hoc analysis showed that the $\mathrm{KI}+\mathrm{CHI}$ group was significantly different $(p<$ 0.05 ) from the other three groups, which were not significantly different from each other, as analyzed by the total numbers of errors per day.

$\mathrm{A} \boldsymbol{\beta}$ deposition is increased by $\mathrm{CHI}$ in the APP/PS1 KI mice at 2 months p.i. TBI in humans can accelerate amyloid pathology (for review, see Johnson et al., 2010), including the accumulation of APP in injured axons (Gentleman et al., 1993; Sherriff et al., 1994), as well as a rapid development of amyloid plaques in severe TBI cases (Roberts et al., 1994; Ikonomovic et al., 2004). Changes in amyloid pathology have also been reported in TBI studies with $\mathrm{AD}$ mouse models (Uryu et al., 2002; Abrahamson et al., 2006; Tran et al., 2011; Tajiri et al., 2013; Washington et al., 2014). To assess whether CHI altered $\mathrm{A} \beta$ in the APP/PS1 KI mouse, we used three time points: (1) an acute time point of $1 \mathrm{~d}$ p.i. where some previous studies have documented elevated APP and A $\beta$; (2) a 1 month p.i. time point when we see RAWM deficits in injured KI mice; and (3) a chronic time point of 2 months p.i. when there is enhanced amyloid pathology in the KI mice (Murphy et al., 2007).

At 1 d p.i., 8-month-old $\mathrm{KI}+$ sham mice showed only sparse $A \beta$ plaques, and there was no injury-induced increase in $\mathrm{A} \beta$ plaque burden as assessed by $6 \mathrm{E} 10$ staining (Fig. 2a). By 1 month p.i. (9month-old mice), a predicted age-related increase in $\mathrm{A} \beta$ burden was seen in $\mathrm{KI}$ mice, both sham and $\mathrm{CHI}$, but there was no injury-induced change in $\mathrm{A} \beta$ burden. By 2 months p.i. (10-month-old mice), the $\mathrm{A} \beta$ staining had continued to increase with age in the KI mice and was seen throughout the cortex. Quantification of the $\mathrm{A} \beta$-positive staining area in mice at 2 months p.i. demonstrated a significant increase in the $\mathrm{A} \beta$ load in CHI mice compared with sham-injured mice ( $p=$ 0.0345; Fig. 2a). Interestingly, at this time point, we observed small $\mathrm{A} \beta$ (6E10) deposits in the $\mathrm{KI}+\mathrm{CHI}$ mice that were not seen in the KI+sham mice (Fig. $2 a$ ); the significance of this observation is not known.

As 6E10 has the potential to detect both A $\beta$ and APP (Gouras et al., 2010), and TBI in mice can induce increases in APP levels (Abrahamson et al., 2006; Loane et al., 2009), we measured A $\beta 1-40$ and $A \beta 1-42-$ specific neo-epitopes to determine whether the increase in $6 \mathrm{E} 10$ staining was specific to $\mathrm{A} \beta$ or reflected changes in APP. The MSD (6E10) A $\beta$ 


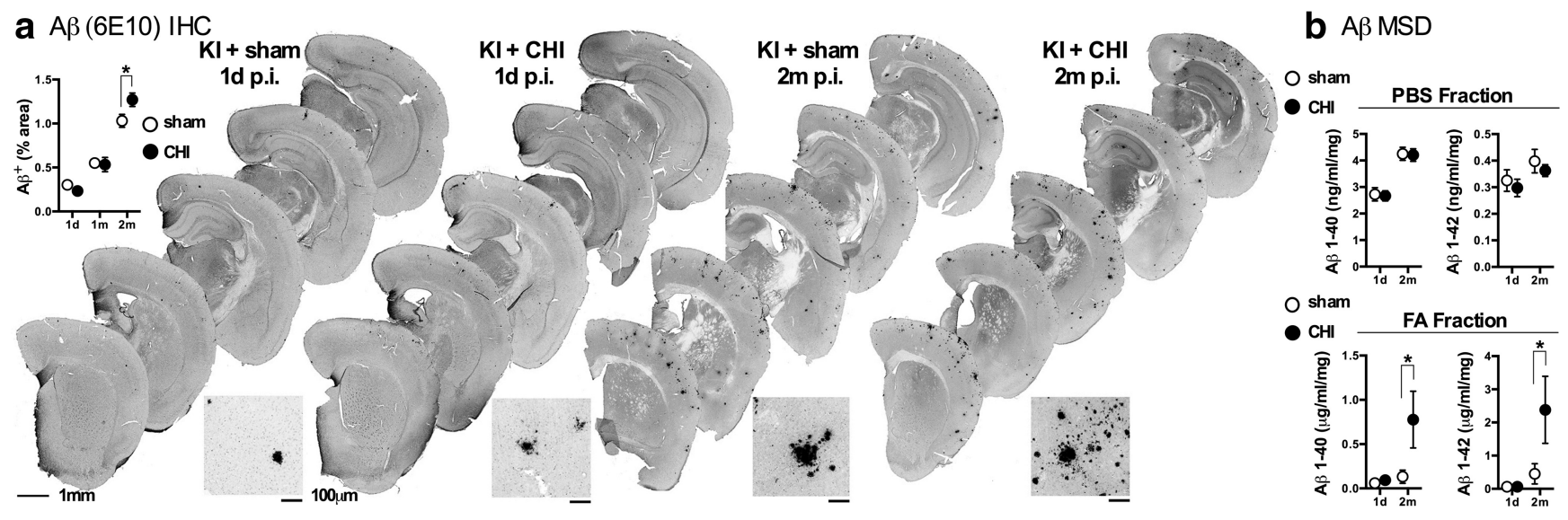

Figure 2. CHI increases A $\beta$ deposition in the APP/PS1 KI mice at 2 months p.i. $\boldsymbol{a}$, At $1 \mathrm{~d}$ and 1 month p.i., there were no observable differences in $A \beta$ staining respective to injury, but by 2 months p.i., the $\mathrm{KI}+\mathrm{CHI}$ group had significantly more staining in the cortex compared with the $\mathrm{KI}+$ sham group, as determined by Aperio ScanScope digital quantification of $6 \mathrm{E} 10 \mathrm{IHC}$. In addition, many small $\mathrm{A} \beta$ deposits were seen in the $\mathrm{KI}+\mathrm{CHI}$ mice that were not present in the $\mathrm{KI}+$ sham mice. $\boldsymbol{b}$, Levels of soluble (PBS fraction) and aggregated (FA fraction) $A \beta 1-40$ and $A \beta 1-42$ in the cortex were measured by MSD ELISA. No injury-induced changes were observed in the levels of $A \beta 1-40$ or $A \beta 1-42$ in the PBS soluble fraction at either $1 \mathrm{~d}$ or 2 months. For the FA fraction, there was a significant injury-induced increase in A $\beta 1-40$ and A $\beta 1-42$ levels at the 2 month p.i. time point ( $n=10-14$ per group). ${ }^{*}$ Denotes significant difference between $\mathrm{KI}+$ sham vs. $\mathrm{KI}+\mathrm{CHI}$.

ELISA uses $\mathrm{A} \beta 1-40$ - and $\mathrm{A} \beta 1-42$ - specific neo-epitopes as capture antibodies and a $6 \mathrm{E} 10$ detection antibody, thereby only measuring $\mathrm{A} \beta$ and not APP. As shown in Figure $2 b$, biochemical determination of the PBS soluble and formic acid (FA) soluble $\mathrm{A} \beta 1-40$ and $\mathrm{A} \beta 1-42$ levels at 2 months p.i. showed a marked, but variable, increase in both $A \beta 1-40$ and $A \beta 1-42$ in the FA fraction in the $\mathrm{CHI}$ compared with sham mice $(\mathrm{A} \beta 1-40, p=$ 0.023; $\mathrm{A} \beta 1-42, p=0.0347$ ), but no change in the PBS soluble fraction. Although the $\mathrm{CHI}$ model used in this study was of insufficient severity to induce a rapid accumulation of $\mathrm{A} \beta$, the mild injury did cause increased $\mathrm{A} \beta$ pathology at this chronic time point. It will be important in future studies to carefully characterize $\mathrm{A} \beta$ processing and clearance pathways between the 1 month p.i. and 2 months p.i time point to elucidate the mechanism of this observation.

\section{APP/PS1 KI mice show an altered temporal cytokine and chemokine response following a CHI compared with WT mice}

Disease- and injury-induced overproduction of proinflammatory cytokines in the CNS (especially IL- $1 \beta$, IL-6, and TNF $\alpha$ ) is associated with degenerative disease processes (Van Eldik et al., 2007; McCoy and Tansey, 2008). Therefore, we hypothesized that the cognitive deficits in the injured KI mice might be associated with a heightened and/or prolonged proinflammatory cytokine response compared with the injured WT mice. To test this, we measured gene expression (Fig. $3 a$ ) and protein levels (Fig. $3 b$ ) for IL-1 $\beta$, IL-6, and TNF $\alpha$ in the cortex at select times after the CHI (statistics are shown in Table 1). At the mRNA level, the $\mathrm{WT}+\mathrm{CHI}$ and the $\mathrm{KI}+\mathrm{CHI}$ groups showed a different temporal pattern of expression, with the peak of the proinflammatory cytokines not occurring until $7 \mathrm{~d}$ p.i. in the $\mathrm{KI}+\mathrm{CHI}$ mice. In contrast to the gene expression, the changes in protein levels of IL- $1 \beta$, IL-6, and TNF $\alpha$ were largely indistinguishable between the $\mathrm{WT}+\mathrm{CHI}$ and the $\mathrm{KI}+\mathrm{CHI}$ groups, as both groups showed a similar temporal pattern in proinflammatory cytokine increase compared with their respective control groups (Fig. 3b; Table 1).

Head injury also induces an increase in IL-10 production (Morganti-Kossmann et al., 2007), an anti-inflammatory cytokine critical to in vivo inflammation responses (Saraiva and O'Garra, 2010). Therefore, mRNA and protein levels for IL-10 were measured in the cortex at multiple time points after the $\mathrm{CHI}$ or sham surgery to determine whether the KI mice might have an altered anti-inflammatory response compared with the WT mice. The KI+CHI mice did not manifest an early IL-10 response to the injury, in contrast to the WT $+\mathrm{CHI}$ mice response (Fig. $3 a$; Table 1). The pattern of IL-10 protein levels was similar to the mRNA, but the protein measurements were near the lower limits of assay detection, potentially contributing to greater variance due to signal-to-noise issues (Fig. $3 b$ ). Regardless, the early antiinflammatory IL-10 response seen in the WT $+\mathrm{CHI}$ mice was not evident in the $\mathrm{KI}+\mathrm{CHI}$ group. This raises the possibility that the $\mathrm{KI}+\mathrm{CHI}$ group is not able to mount the counteracting arm of the physiological axis in which IL-10 counterbalances the increased IL- $1 \beta$, IL-6, and TNF $\alpha$ proinflammatory response, or the IL-10 response is shifted to an entirely different time window not examined in this study.

Chemokines, among other functions, have important chemoattractant properties to direct the recruitment of leukocytes to sites of injury or inflammation. Recruitment of monocytes to sites of injury is the function of the CC chemokine family (Ubogu et al., 2006; Viola and Luster, 2008), so named because the first two cysteine residues are adjacent. Therefore, we measured mRNA levels of four CC chemokines key to the recruitment of monocytes. As shown in Figure $3 c$, the $\mathrm{KI}+\mathrm{CHI}$ group did not exhibit the early chemokine response seen in the $\mathrm{WT}+\mathrm{CHI}$ group. The WT $+\mathrm{CHI}$ group showed a rapid increase (by $9 \mathrm{~h}$ ) in CCL2 and CCL4 gene expression compared with the WT + sham mice. In contrast, the peak chemokine response of the $\mathrm{KI}+\mathrm{CHI}$ group was at $7 \mathrm{~d}$ (Fig. $3 c$; Table 1 ).

\section{The temporal patterns of microglia markers change after $\mathrm{CHI}$} Microglia play an important role in maintaining the health of the CNS but also contribute significantly to the pathophysiology following activation in response to an acute brain injury and in chronic neurodegenerative disease (Loane and Byrnes, 2010; Mosher and Wyss-Coray, 2014). Because $\mathrm{A} \beta$ is a potent activator of microglia, we hypothesized that the microglia in the APP/PS1 KI mice would be "primed," such that the CHI would lead to an exaggerated microglia response compared with the WT $+\mathrm{CHI}$ mice. To test this prediction, we visualized CHI-induced microglia morphological changes by IBA1 IHC. CHI produced a reactive microglia 
a cytokine gene expression in cortex

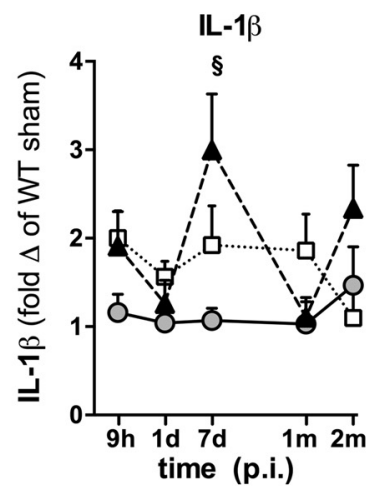

IL-6

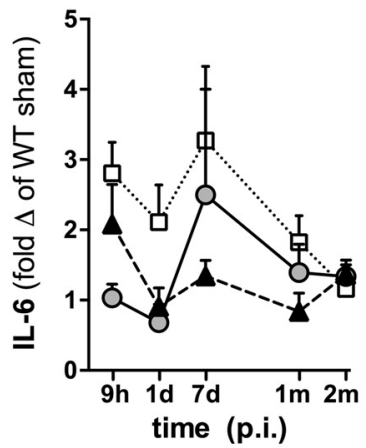

\section{$\cdot \square \cdot \mathrm{WTCHI}$-O $\mathrm{KI}$ sham $\mathbf{2} \cdot \mathbf{\mathrm { KICHI }}$}

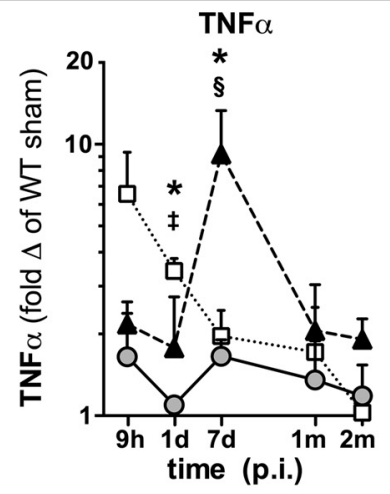

IL-10

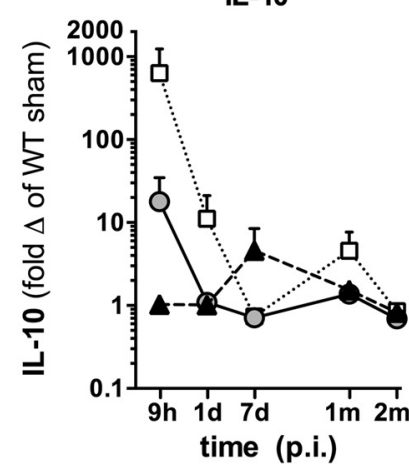

b cytokine protein levels in cortex
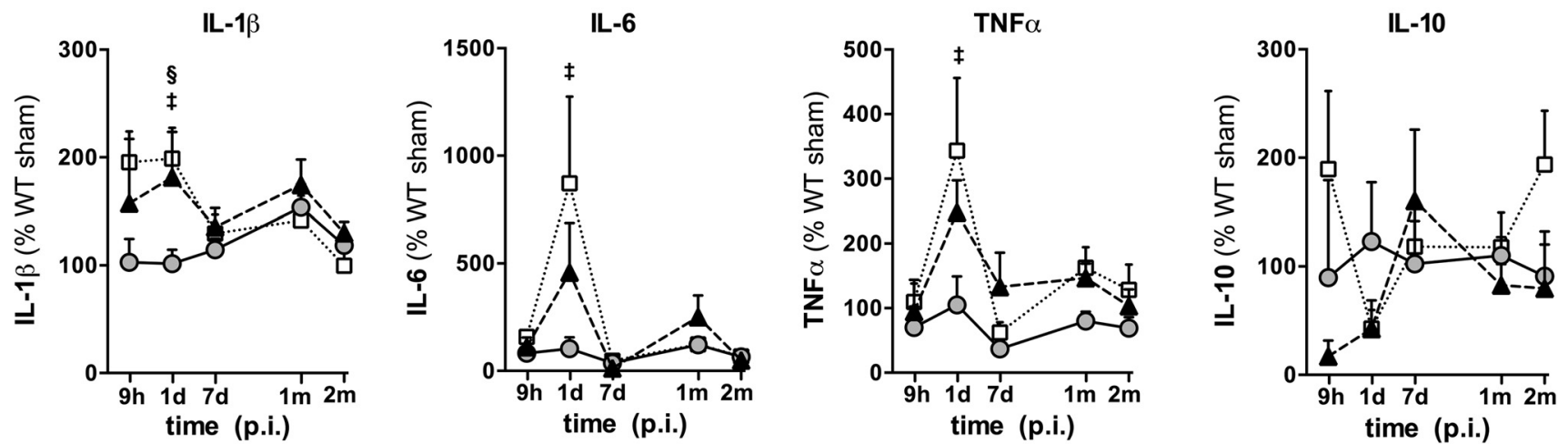

C CC chemokine gene expression in cortex

CCL2

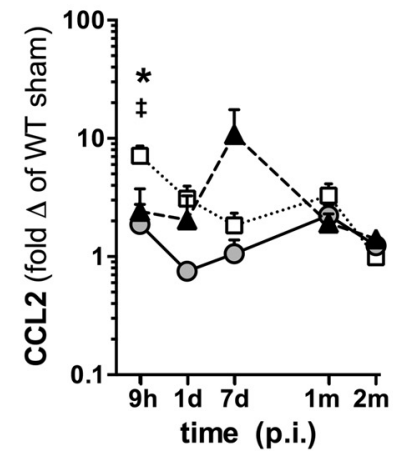

CCL3

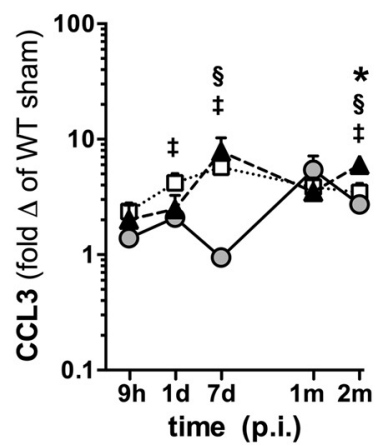

CCL4

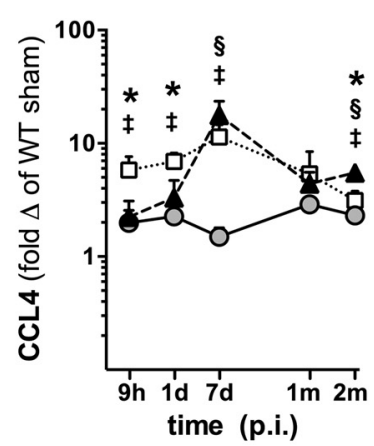

\section{CCL5}

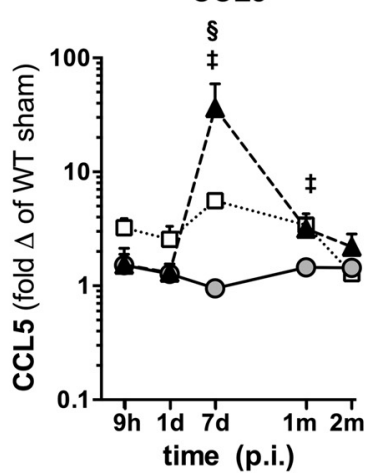

Figure 3. APP/PS1 KI mice show an altered temporal cytokine and chemokine response following a CHI compared with WT mice. $\boldsymbol{a}$, The temporal patterns of proinflammatory cytokine (IL-1 $\beta$, IL-6, TNF $\alpha$ ) gene expression differed in KI and WT mice after injury, with delayed peak levels in the KI mice ( $n=5$ or 6 per group). $\boldsymbol{b}$, However, proinflammatory cytokine protein levels showed a similar pattern of upregulation in KI and WT mice after injury ( $n=7-14$ per group). The injured KI mice failed to induce an early increase in the anti-inflammatory cytokine IL-10 but showed a delayed peak at $7 \mathrm{~d}$ p.i., at both the gene expression level (a) ( $n=5$ or 6 per group) and protein level (b) ( $n=7-14$ per group). c, The injured KI mice did not show the early ( $9 \mathrm{~h}$ and $1 \mathrm{~d})$ upregulation of inflammatory chemokines seen in the WT + CHI mice but instead showed a striking peak chemokine response at $7 \mathrm{~d}$. Statistics summary is shown in Table 1. ${ }^{*}$ Denotes significant difference between WT + CHI vs. KI + CHI. ‡Denotes significant difference between WT + sham vs. WT + CHI. §Denotes significant difference between KI + sham vs. KI + CHI.

response, with the most pronounced morphological change occurring at $7 \mathrm{~d}$ p.i. (Fig. $4 a, b)$. Quantification of IBA1 ${ }^{+}$staining (Fig. $4 c$ ) showed no differences between $\mathrm{WT}+\mathrm{CHI}$ and $\mathrm{KI}+\mathrm{CHI}$ mice at the $1 \mathrm{~d}$ and $7 \mathrm{~d}$ p.i. time points. By 2 months p.i., the microglia activation in the injured WT mice had resolved and was not significantly different from the sham WT mice (for statistical comparisons, see Table 2). At 2 months p.i., the IBA $1^{+}$microglia in the KI mice were still elevated compared with the WT mice; however, there was no difference between the injured and sham $\mathrm{KI}$ mice. As shown in Figure $4 a$, some of the microglia staining in the KI mice at 2 months p.i. appeared in clustered regions, which may represent areas where $\mathrm{A} \beta$ plaques are deposited. Overall, our data show that the WT and KI mice have a similar initial injuryinduced increase in IBA1 staining, which decreases over time in the WT mice but stays elevated in the KI mice $(\mathrm{KI}+$ sham and $\mathrm{KI}+\mathrm{CHI})$.

A number of gene expression markers have now been defined that are associated with different microglia activation states and disease-specific molecular signatures (Chiu et al., 2013; Hickman et al., 2013; Butovsky et al., 2014). Although analysis of the large 
a IBA1 IHC in the cortex
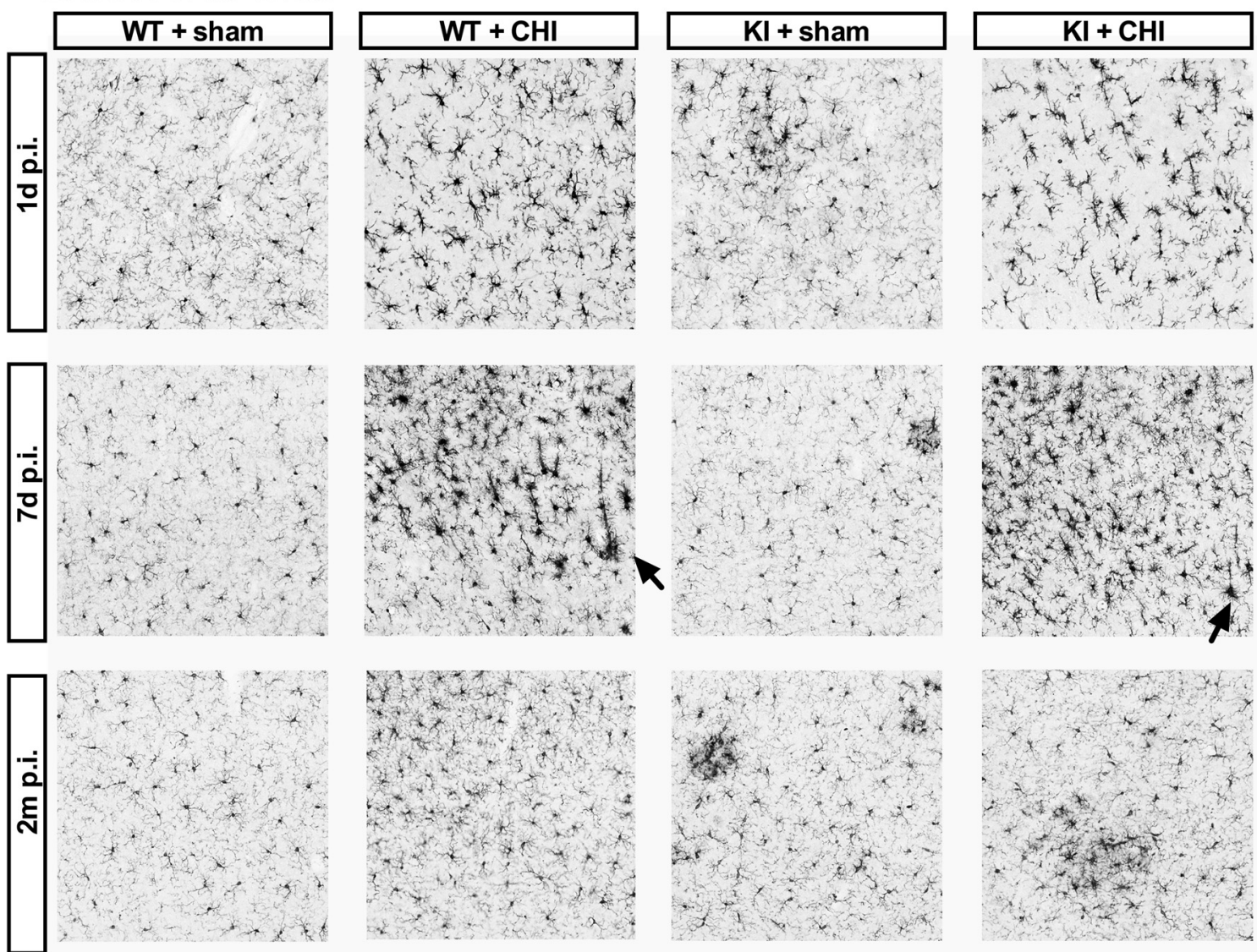

b IBA $1 \mathrm{IHC}$ in the cortex at $7 \mathrm{~d}$ p.i.
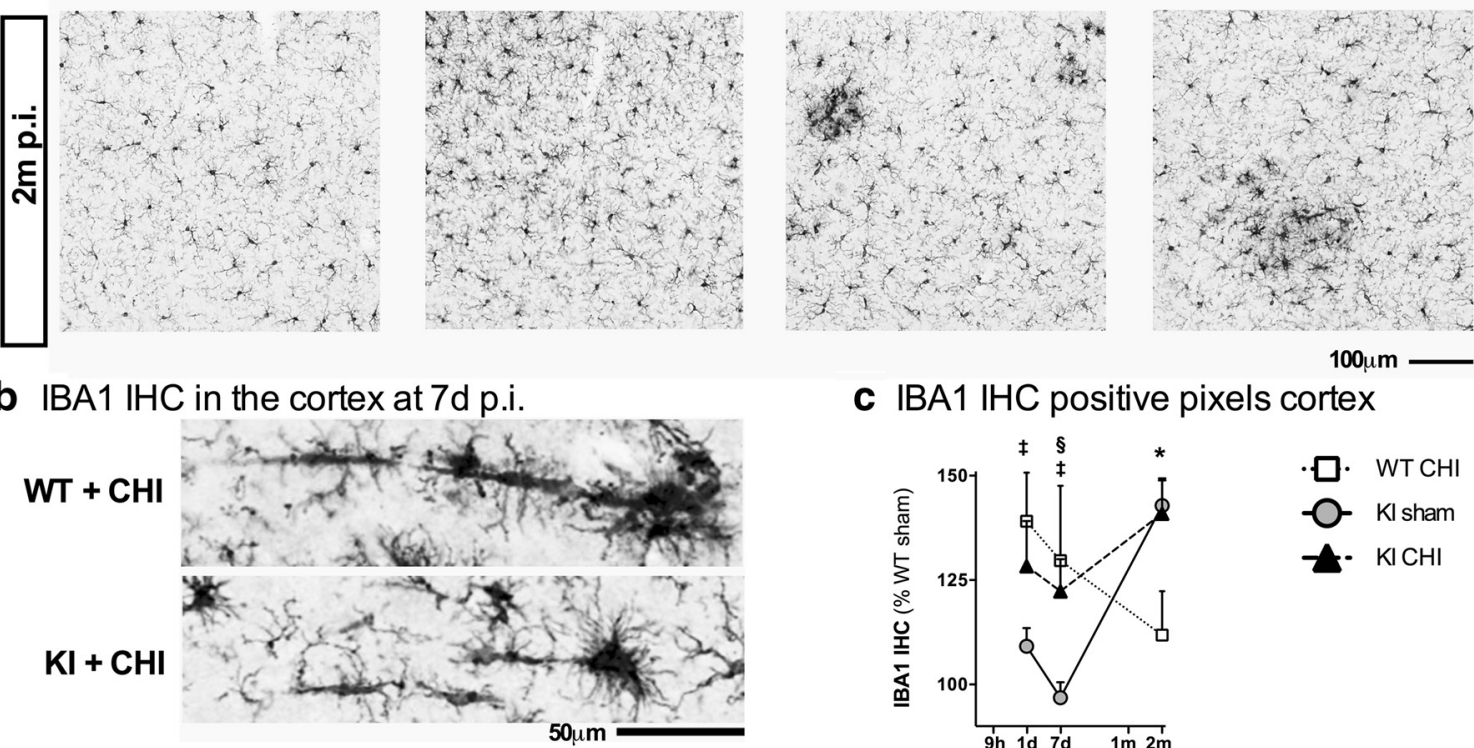

$100 \mathrm{um}$

C IBA1 IHC positive pixels cortex

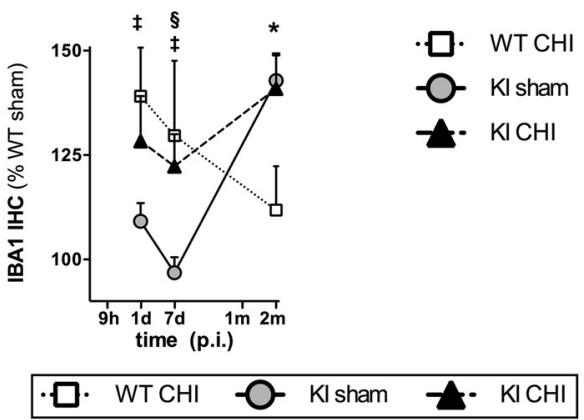

d gene expression in cortex
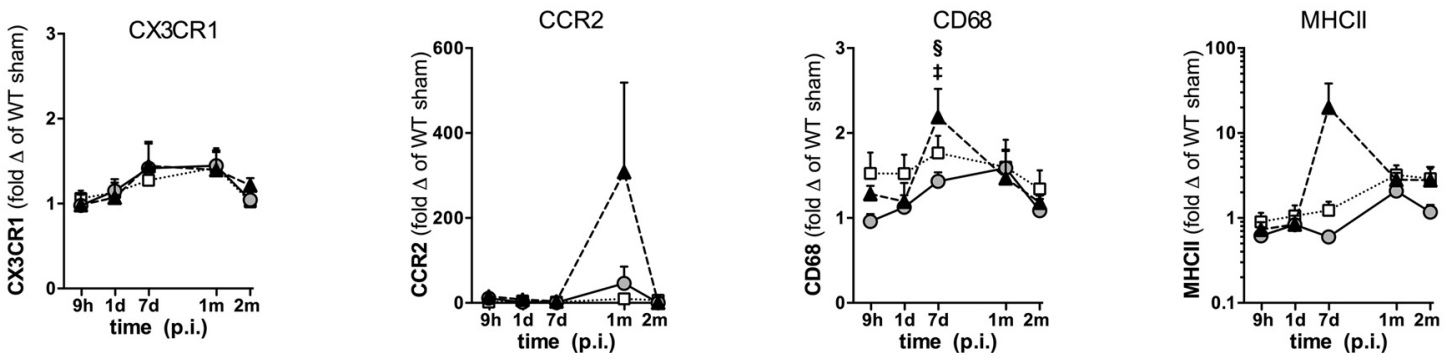

Figure 4. The temporal patterns of microglia markers change after $C H I . a$, IBA1-positive staining in the cortex at $1 \mathrm{~d}, 7 \mathrm{~d}$, and 2 months p.i. shows changes in microglia morphology after CHI. Some of the microglia in the KI mice appeared in clustered regions, which may represent areas where A $\beta$ plaques are deposited. $\boldsymbol{b}$, Higher-magnification view of area indicated by arrows in the $7 \mathrm{~d}$ p.i CHI groups. c, Quantification of IBA1-positive pixels in the cortex using the Aperio ScanScope ( $n=7-14$ per group) shows that WT and KI mice have a similar early $(1 \mathrm{~d}, 7 \mathrm{~d})$ injury-induced increase in IBA1 staining, which decreases by 2 months in the WT mice but stays elevated in the KI mice (KI+ sham and KI+CHI). $\boldsymbol{d}$, Gene expression for microglia/macrophage markers revealed some differences between WT and KI mice after injury, with KI mice showing a peak for CD68 and MHCII expression at $7 \mathrm{~d}$ after the CHI $(n=5$ or 6 per group). Statistics summary is shown in Table $2 .{ }^{*}$ Denotes significant difference between WT + CHI vs. KI + CHI. ‡Denotes significant difference between WT + sham vs. WT + CHI. §Denotes significant difference between $\mathrm{KI}+$ sham vs. $\mathrm{KI}+\mathrm{CHI}$. 
number of markers that have been proposed to be microglia/ macrophage specific would be informative, it is well beyond the scope of this study. Therefore, we selected four standard gene expression markers to provide an initial survey of the microglia response in the APP/PS1 KI mice following the CHI. We measured the gene expression of a marker associated with microglia (CX3CR1) and with macrophages (CCR2) (Mizutani et al., 2012), and two classical histological markers (CD68 and MHCII) of microglia/macrophage activation (Fig. 4d). Expression of CX3CR1 in the cortex was unchanged by injury or genotype. A spike in CCR2 expression was seen at 1 month p.i., with the greatest increase in the $\mathrm{KI}+\mathrm{CHI}$ mice compared with the other groups. Expression of $\mathrm{CD} 68$ and MHCII followed a pattern in the KI+CHI mice similar to that of the proinflammatory cytokine and chemokine expression, with a peak response occurring at the $7 \mathrm{~d}$ p.i. time point. The results suggest that there may be a functionally unique microglia/macrophage response in the $\mathrm{KI}+\mathrm{CHI}$ mice occurring $\sim 7$ d p.i. Therefore, our initial microglia/macrophage gene expression results suggest that a more detailed molecular characterization of isolated cells by flow cytometric analysis, with subsequent gene expression analysis, is warranted in the future to fully characterize the magnitude and type of the microglia and infiltrating macrophage response after the $\mathrm{CHI}$, and to determine whether and how this response is altered in the context of $\mathrm{AD}$ pathology.

\section{$\mathrm{CHI}$ induces persistent astrocyte activation and a delayed temporal profile of gene expression changes in APP/PS1 KI mice}

Astrocytes in all CNS disorders, whether from acute brain injury or chronic neurodegeneration, adopt phenotypes with altered morphological and biochemical properties. This activated astrocyte response can result in a loss of homoeostatic functions, such as glutamate and potassium homeostasis, movement of water, brain metabolism, and regulation of inflammation (Verkhratsky et al., 2012). When astrocytes become activated, they can also impair synaptic function and contribute to cognitive impairment (Furman et al., 2012). GFAP IHC is a common method used to visualize astrocyte activation and morphological changes. Figure 5 shows the activated astrocyte response after $\mathrm{CHI}$. The $\mathrm{WT}+\mathrm{CHI}$ group showed an increase in GFAP staining at $1 \mathrm{~d}$ and $7 \mathrm{~d}$ p.i., which decreased by 2 months p.i. (Fig. $5 a$ ). In the $\mathrm{KI}+\mathrm{CHI}$ mice, GFAP staining in the cortex at $1 \mathrm{~d}$ and $7 \mathrm{~d}$ p.i. was largely associated with what appear to be plaques. The most striking change in GFAP staining occurred at 2 months p.i. in the $\mathrm{KI}+\mathrm{CHI}$ mice. Quantification of the GFAP staining (Fig. $5 b$ ) showed a large increase in GFAP in the $\mathrm{KI}+\mathrm{CHI}$ mice at this chronic time point, significantly greater than the normal increase in GFAP in the $\mathrm{KI}+$ sham mice at this age.

We further characterized the temporal pattern of the activated astrocyte responses by measuring changes in gene expression of four astrocyte markers. In WT + CHI mice, GFAP gene expression increased early, reaching a peak at $1 \mathrm{~d}$ p.i. and slowly subsiding over 2 months (Fig. $5 c$ ). In contrast, in $\mathrm{KI}+\mathrm{CHI}$ mice, the increase in GFAP gene expression was delayed, reaching a peak at the $7 \mathrm{~d}$ p.i. time point. GFAP expression remained elevated at 2 months p.i. in the injured KI mice relative to sham, in agreement with the GFAP IHC data. The temporal pattern of gene expression for vimentin was similar to that of GFAP, with $\mathrm{KI}+\mathrm{CHI}$ mice showing a delayed increase ( $7 \mathrm{~d}$ peak) that remained elevated at the 2 month time point.

A recent study (Zamanian et al., 2012) identified a number of genes that were highly enriched in astrocytes from an ischemic stroke brain injury model compared with the control. Two genes that were highly induced in isolated astrocytes from the injury model were lipocalin 2 (Lcn2) and pentraxin $3(\operatorname{Ptx} 3)$. Lcn2 induction has been reported to be detrimental to neurological outcomes in stroke models (Egashira et al., 2014; Jin et al., 2014) and in a spinal cord injury model (Rathore et al., 2011), but beneficial in experimental autoimmune encephalomyelitis (Berard et al., 2012). Ptx3 belongs to the superfamily of proteins that includes C-reactive protein (for review of Ptx, see Daigo et al., 2014). In an ischemic brain injury model, Ptx3 deficiency was associated with increased infarct volume, increased blood-brain barrier leakage, and prolonged edema (Rodriguez-Grande et al., 2014). In response to ischemic brain injury, Lcn2 and Ptx3 genes showed a rapid upregulation by $1 \mathrm{~d}$ p.i., with a steady return to baseline by $7 \mathrm{~d}$ p.i.; longer time points were not measured (Zamanian et al., 2012).

Therefore, we measured Lcn2 and Ptx3 gene expression at different times after $\mathrm{CHI}$ in WT and $\mathrm{KI}$ mice. WT+CHI mice showed a rapid increase in both Lcn2 and Ptx3, and a return toward baseline by $7 \mathrm{~d}$ p.i. (Fig. $5 c$; Table 2), in agreement with the findings in an ischemic stroke injury model (Zamanian et al., 2012). In contrast, $\mathrm{KI}+\mathrm{CHI}$ mice failed to upregulate $\mathrm{Lcn} 2$ and Ptx3 at the $9 \mathrm{~h}$ and $1 \mathrm{~d}$ p.i. time points but showed a significant increase at later time points $(7 \mathrm{~d}$ p.i. for Ptx 3 and 2 months for Lcn2) (Fig. 5c; Table 2). These results provide further support for altered astrocyte activation in response to $\mathrm{CHI}$ in the KI mice. In future experiments, ex vivo gene expression analysis of isolated astrocytes will be important to fully characterize the magnitude and type of the astrocyte responses after the $\mathrm{CHI}$, and to further explore mechanisms associated with the altered astrocyte responses in the context of AD pathology.

\section{Treatment of APP/PS1 KI mice with MW151, a small- molecule inhibitor of glia neuroinflammatory responses, prevents $\mathrm{CHI}$-induced cognitive impairment}

MW151 was developed (Hu et al., 2007) by using a validated mouse model (Craft et al., 2004a, b, 2006) and discovery approach, to develop novel small molecules that selectively attenuate stressor-induced upregulation of neuroinflammatory responses from activated glia. We previously reported (Bachstetter et al., 2012) that treatment of APP/PS1 KI mice with MW151 in the early-stage time window of age-related increase in proinflammatory cytokines could prevent the resultant synaptic dysfunction. In addition, we recently reported that MW151 can suppress injury-induced IL- $1 \beta$ and IL- 6 production and attenuate cognitive impairment in WT mice following a CHI (Bachstetter et al., 2015). Based on this precedent, we treated mice with MW151 (5 $\mathrm{mg} / \mathrm{kg} / \mathrm{d}$; i.p.) to confirm the effectiveness of MW151 in suppressing the neuroinflammatory response (Fig. $6 a-e$ ). Because there was a $7 \mathrm{~d}$ p.i. peak in several neuroinflammatory gene expression markers in the $\mathrm{KI}+\mathrm{CHI}$ mice, we initiated treatment of cohort 6 (Fig. 6) with MW151 at day 7 p.i. We administered MW151 once daily for $4 \mathrm{~d}$, then killed mice at $\sim 3 \mathrm{~h}$ after the last injection of MW151 on day 10 p.i. to determine whether MW151 could suppress the injury-induced neuroinflammatory response (Fig. 6a). Under these conditions, MW151 treatment suppressed the proinflammatory cytokine response (Fig. $6 b$ ), had no effect on IBA staining (Fig. $6 c$ ), and reduced GFAP staining (Fig. $6 c$ ). Consistent with prior results in the age-related intervention study (Bachstetter et al., 2012), there was no effect of MW151 treatment on $\mathrm{A} \beta$, as assessed histologically (Fig. $6 d$ ) and biochemically (Fig. 6e).

After confirming that MW151 had the expected pharmacodynamics effect related to its mechanism of action (i.e., sup- 
a GFAP IHC
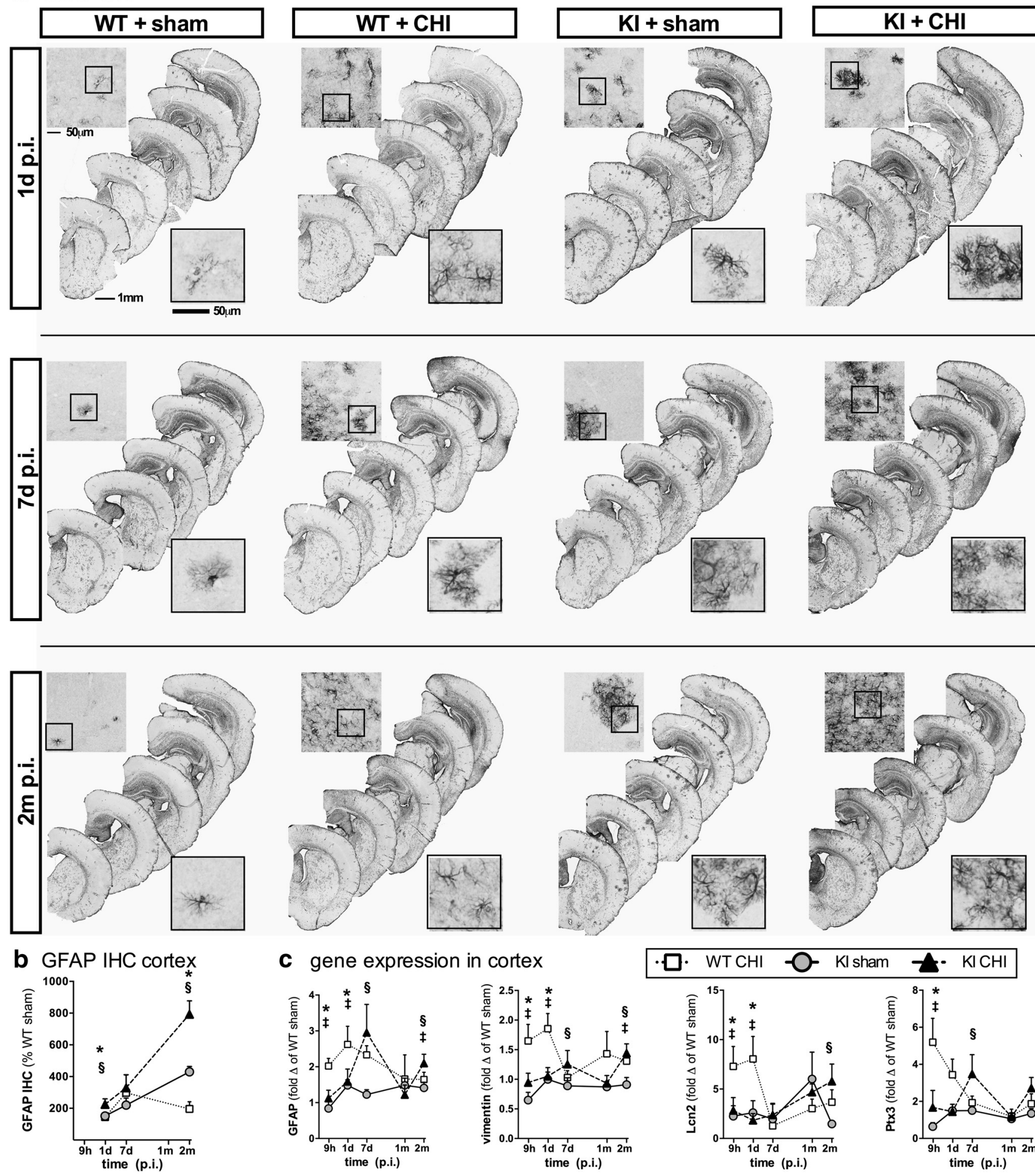

Figure 5. CHI induces persistent astrocyte activation and a delayed temporal profile of astrocyte-associated gene expression changes in the APP/PS1 KI mice. $\boldsymbol{a}$, GFAP staining at low magnification shows the regional increase in staining seen in the cortex of the $\mathrm{CHI}$ groups. The higher-magnification insets were taken from the middle brain sections and from the same regions of the cortex to show the morphological appearance of the astrocytes. $\boldsymbol{b}$, Quantification of GFAP staining was done with the Aperio ScanScope, using the entire neocortex as the region of interest. Astrocyte activation remains elevated at 2 months p.i. in injured KI mice ( $n=7-14$ per group). $c$, The temporal patterns of astrocytic gene expression (GFAP, vimentin, Lcn2, and Ptx3) differed between WT and KI mice after injury. The injured WT mice showed an early increase in gene expression $(9 \mathrm{~h}, 1 \mathrm{~d})$ and then a decline in expression levels, whereas the injured KI mice showed a more delayed initial increase and more persistent response ( $n=5$ or 6 per group). For example, GFAP, vimentin, and Ptx 3 showed a peak in gene expression in the KI mice at $7 \mathrm{dp}$.i., and all four genes remained elevated at 2 months. Statistics summary is shown in Table 3. ${ }^{*}$ Significant difference between WT + CHI vs. KI + CHI; ‡Significant difference between WT + sham vs. WT + CHI. §Significant difference between $\mathrm{KI}+$ sham vs. KI + CHI. 
a study design for cohort 6: $10.5 \mathrm{~d}$ p.i.

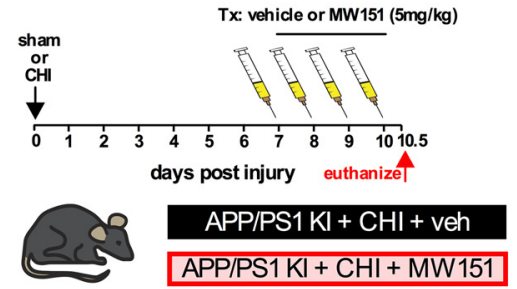

b cytokine MSD

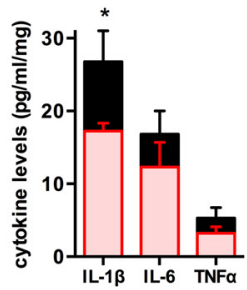

C glia IHC

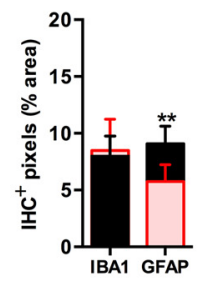

d $\mathrm{A} \beta \mathrm{HC}$

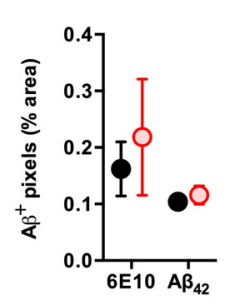

e $A B M S D$

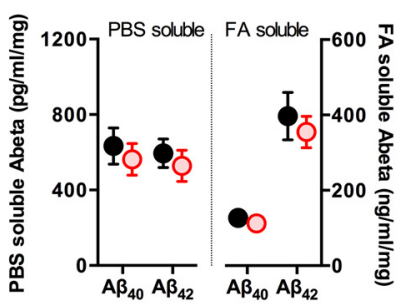

f study design for cohort $7: 32 \mathrm{~d} \mathrm{p.i.}$

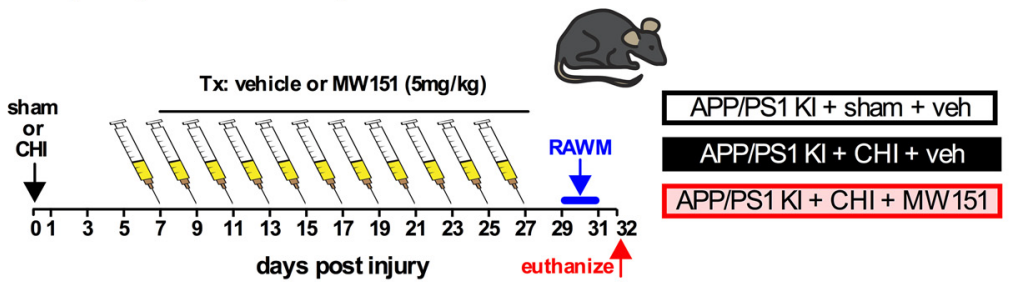

g RAWM

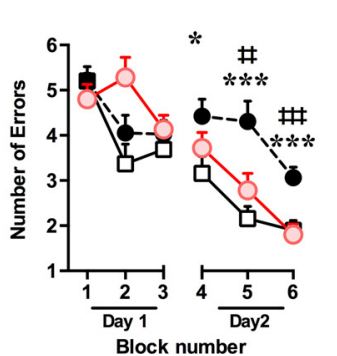

h RAWM

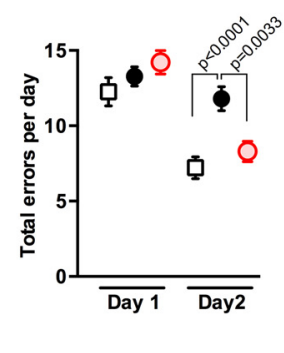

i cytokine MSD

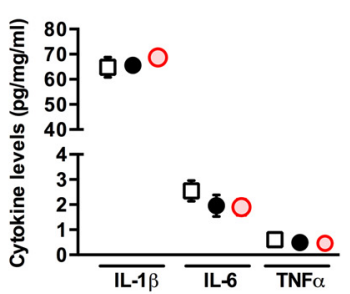

j gialHC

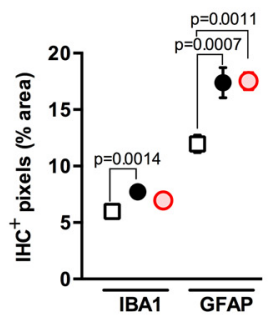

$\mathbf{k}_{A \beta} \mathrm{HC}$

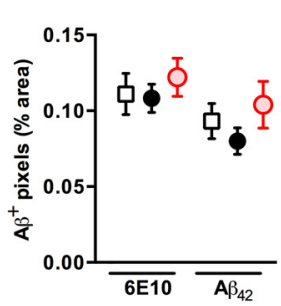

I ABMSD
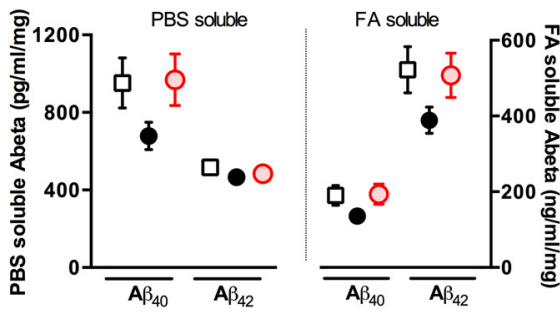

Figure 6. Treatment of APP/PS1 KI mice with MW151, a small-molecule inhibitor of glia neuroinflammatory responses, prevents CHI-induced cognitive impairment. $\boldsymbol{a}$, In cohort 6, mice were treated with MW151 ( $5 \mathrm{mg} / \mathrm{kg}$ ) or saline vehicle by intraperitoneal injection once daily on days $7-10$ p.i. ( $n=5$ or 6 per group). $\boldsymbol{b}$, Injury-induced proinflammatory cytokine production and (c) astrocytosis, but not microglia, were reduced by MW151 treatment. MW151 treatment had no effect on (d) A $\beta$ IHC or (e) PBS-soluble or FA-soluble A $\beta 1$ - 40 or A $\beta 1$ - 42 levels. $f$, In cohort 7, mice were treated with MW151 $(5 \mathrm{mg} / \mathrm{kg}$ ) or saline vehicle by intraperitoneal injection every other day, from day 7 to day 27 p.i. ( $n=10-14$ per group). On day 29 p.i., mice were tested in the $2 \mathrm{~d}$ RAWM task. The learning curve $(\boldsymbol{g})$ and the total number of errors per day $(\boldsymbol{h})$ show that MW151 prevents the $\mathrm{CHI}$-induced cognitive impairment. $\boldsymbol{i}$, There was no change in cytokine levels in any experimental group at this 32 p.i. time point. $j$, There was a significant increase in IBA1 and GFAP IHC in the injured mice compared with the sham mice, but the MW151-treated mice showed little (IBA1) to no

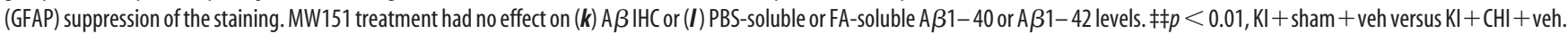
$\neq \neq \neq p<0.001, \mathrm{KI}+$ sham + veh versus $\mathrm{KI}+\mathrm{CHI}+$ veh. ${ }^{*} p<0.05, \mathrm{KI}+\mathrm{CHI}+$ veh versus $\mathrm{KI}+\mathrm{CHI}+\mathrm{MW151} .{ }^{* *} p<0.01, \mathrm{KI}+\mathrm{CHI}+$ veh versus $\mathrm{KI}+\mathrm{CHI}+\mathrm{MW} 151 .{ }^{* * *} p<0.001, \mathrm{KI}+\mathrm{CHI}+$ veh versus $\mathrm{KI}+\mathrm{CHI}+\mathrm{MW} 151$.

pression of the injury-induced neuroinflammatory response), we tested whether repeat administration with MW151 could attenuate the injury-induced cognitive deficits. As outlined in Figure $6 f$, cohort 7 mice were treated with MW151 or saline vehicle intraperitoneally every other day from day 7 to 27 p.i. Following $2 \mathrm{~d}$ without treatment, to minimize any stressrelated effects on the animals' behavior, the mice were tested in the RAWM. As shown in Figure $6 g$, there was a significant cognitive impairment in the injured KI mice (significant effect of training, $p<0.0001$; and experimental group, $p=0.0081$ ). Post hoc analysis showed that the $\mathrm{KI}+\mathrm{CHI}+$ veh group was significantly different $(p<0.05)$ from the other two groups. Importantly, on day 2 of the RAWM task, injured mice treated with MW151 made significantly fewer errors than the injured mice treated with vehicle, and MW151-treated mice were not significantly different from sham controls (Fig. 6h). Thus, the RAWM data support the hypothesis that the dysregulated neuroinflammatory response seen in the KI mice subjected to $\mathrm{CHI}$ may be one of the contributing factors that leads to cognitive impairment following injury.
At day 32 p.i., mice were killed, and we measured cytokine levels (Fig. 6i), IBA1 and GFAP IHC (Fig. 6j), and A $\beta$ by histology (Fig. 6k) and biochemistry (Fig. 6l), to examine other pathological endpoints in addition to the functional RAWM endpoint. Levels of cytokines (IL-1 $\beta$, IL-6, TNF $\alpha$ ) did not change with injury or MW151 treatment at this chronic time point ( $32 \mathrm{~d}$ p.i.), and MW151 did not suppress the cytokine levels below the basal levels seen in the sham mice (Fig. 6i). IBA1 and GFAP IHC staining showed a significant increase in the injured mice compared with the sham mice, but the MW151-treated mice showed little (IBA1) to no (GFAP) suppression of CHI-induced glial activation (Fig. 6j). There was no effect in any of the experimental groups on $\mathrm{A} \beta \mathrm{IHC}$ using either $6 \mathrm{E} 10$ - or $\mathrm{A} \beta 1-42$-specific antibodies (Fig. 6k). Biochemical measurement of PBS- and FAsoluble $A \beta 1-40$ and $A \beta 1-42$ also showed no significant differences in any of the groups (Fig. 6l).

\section{Discussion}

There are three key findings from the studies reported here. First, a single, comparatively mild, diffuse brain injury admin- 

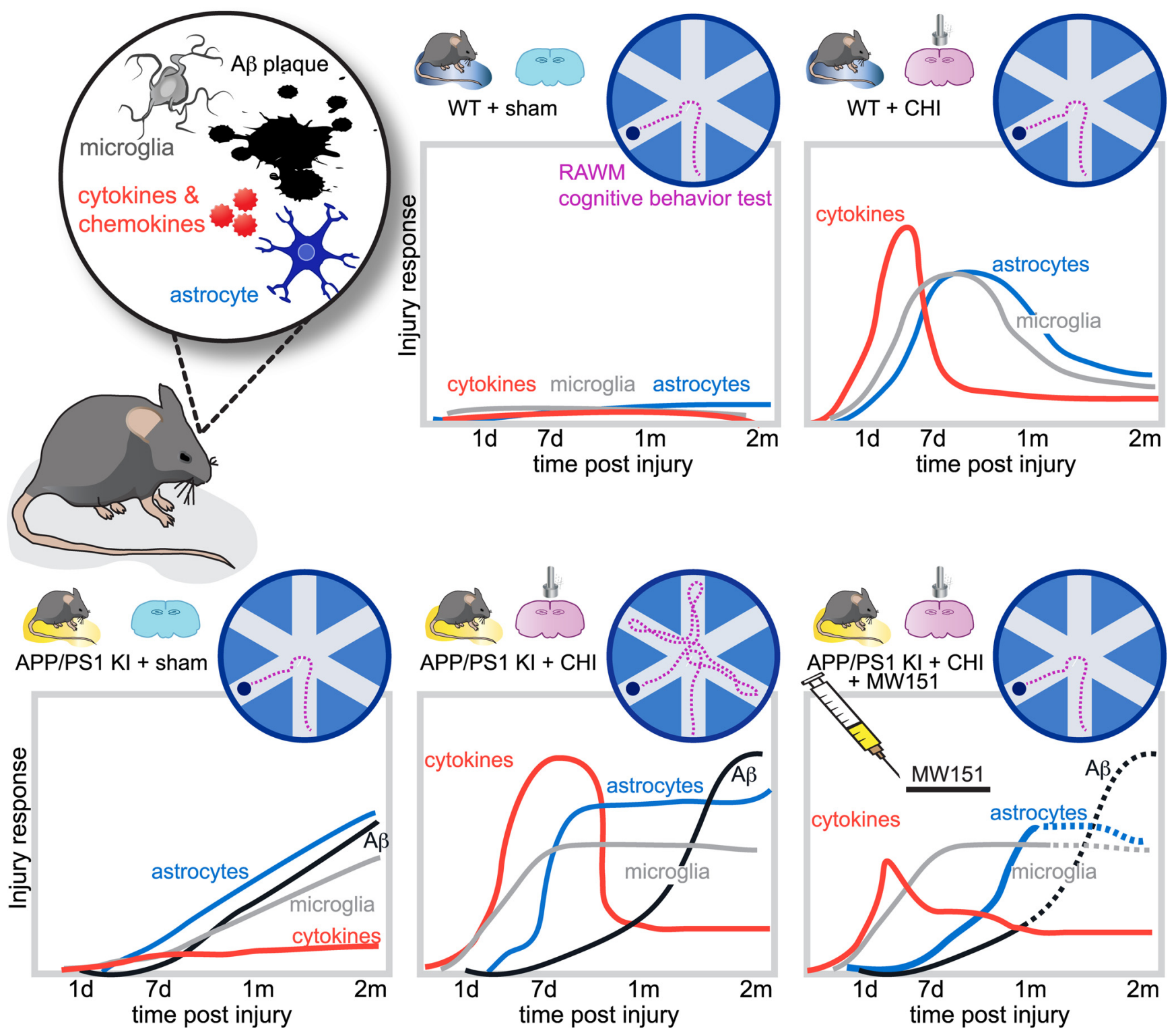

Figure 7. Summary of CHI-induced changes in WT and APP/PS1 KI mice. In WT + sham mice, there are low levels of proinflammatory cytokines/chemokines and reactive microglia and astrocytes. In WT + CHI mice, there is a rapid increase and resolution of the proinflammatory cytokine/chemokine response. This is followed by activation of microglia and astrocytes that slowly resolves over time, with most responses down toward basal levels by the 2 months p.i. time point. In the $\mathrm{KI}+$ sham mice, cytokines and glia are at low levels at the start of the experiment (8-month-old mice). As $\mathrm{A} \beta$ accumulates in the $\mathrm{KI}+$ sham mice with increased age, there is also a concomitant increase in neuroinflammation. In the $\mathrm{KI}+\mathrm{CHI}$ mice, there is an altered temporal neuroinflammatory response compared with the WT +CHI mice. In the injured KI mice, much of the proinflammatory cytokine/chemokine, microglia and astrocyte response is delayed until $7 \mathrm{~d} \mathrm{p.i.} \mathrm{but} \mathrm{then} \mathrm{remains} \mathrm{elevated} \mathrm{and}$ is not resolved at the 2 months p.i. time point. By 2 months p.i., there is also an increase in $\mathrm{A} \beta$ in the $\mathrm{KI}+\mathrm{CHI}$ mice compared with the $\mathrm{KI}+$ sham mice. Treatment of $\mathrm{KI}+\mathrm{CHI}$ mice with the experimental therapeutic (MW151) that selectively attenuates proinflammatory cytokine overproduction reduced the cytokine and astrocyte response to injury. Importantly, MW151 treatment prevented the cognitive deficits in RAWM. Our data support a mechanism by which a dysregulated neuroinflammatory response contributes to increased risk of cognitive impairment after head injury.

istered before onset of age-associated functional deficits and pathology in an AD-relevant mouse model can induce chronic cognitive impairment. Second, there is an altered temporal profile in the injury-induced proinflammatory cytokine increases that could not have been predicted from the prior separate investigations that previously linked the neuroinflammation to neurologic outcomes in both the TBI and the $\mathrm{AD}$ relevant mouse models. Third, intervention with a smallmolecule inhibitor of brain proinflammatory cytokine upregulation prevents the chronic cognitive impairment, providing a linkage of the neuroinflammatory response to the neurologic outcomes. This raises the potential for future development of neuroinflammation biomarkers related both to pathophysiology progression at key time windows and to the effects of such drugs on these pharmacodynamic endpoints.

Specifically, we report that a single mild TBI in the APP/PS1 KI mouse induced an extended neuroinflammation response and a chronic cognitive impairment that persisted even at the 2 months p.i. time point. The astrocyte activation and cytokine responses in the injured KI mice were delayed in onset and were extended in presence compared with the injured WT mice. Treatment during this phase with a small-molecule experimental therapeutic (MW151) that selectively attenuates proinflammatory cytokine upregulation prevented cognitive impairment in injured KI mice, providing a mechanistic link between the altered neuroinflammation and neurologic endpoints. Overall, our data 
indicate that a TBI in the context of emerging $\mathrm{AD}$ pathology leads to greater cognitive impairment that appears to involve an altered neuroinflammatory response mechanism (Fig. 7).

Epidemiological studies and clinical observations have associated a prior head injury with an increased risk of cognitive impairment, earlier onset of dementia, and increased AD neuropathological changes, as well as noting the presence of glia activation in both TBI and AD patients (Johnson et al., 2010; Ramlackhansingh et al., 2011; Shively et al., 2012; Abner et al., 2014). Consistent with the clinical analyses, studies of transgenic $\mathrm{AD}$ mouse models have reported that a moderate-to-severe TBI worsens cognitive performance in the Morris water maze or RAWM (Brody and Holtzman, 2006; Abrahamson et al., 2009; Tajiri et al., 2013). Our results are consistent with the previous studies and extend the association to a mild diffuse TBI model that does not have the tissue loss characteristic of more severe injuries. Additionally, the outcomes with MW151 treatment add a mechanistic linkage between the neuroinflammation and cognitive performance.

An interesting but unresolved aspect of the cytokine response is the difference between the injured KI and WT mice in the after injury increase of the anti-inflammatory cytokine IL-10. The lack of acute IL-10 induction in the injured KI mice might have functional significance, but a mechanistic link between the IL-10 response and subsequent pathological changes in the $\mathrm{KI}+\mathrm{CHI}$ mice, as done with proinflammatory cytokine levels and MW151 treatment, was not explored here. Further, the specifics of an in vivo inflammatory response to injury and disease progression reflects the convergence of multiple physiological axes with their attendant feedback and crosstalk (Van Eldik et al., 2007; WyssCoray and Rogers, 2012; Sama and Norris, 2013), so it is not known whether the IL-10 response in the paradigm studied here is a reflection of secondary responses to changes in proinflammatory cytokines or a more proximal response to the injury itself. The mechanistic role of IL-10 would be interesting to pursue in future investigations with the availability of selective in vivo probes for modulation of IL-10 levels in response to injury or disease progression.

Another interesting correlation was the striking and persistent increase in GFAP staining in the cortex of the $\mathrm{KI}+\mathrm{CHI}$ group. Astrocyte activation as assessed by GFAP staining is correlated with TBI-associated pathophysiologies, such as increased proinflammatory cytokine levels, oxidative stress, and brain edema (Kimelberg, 1992; Kimelberg et al., 1995; Laird et al., 2008; Sofroniew, 2014). However, astrocytes also serve homeostasis functions (Schousboe et al., 2004; Simard and Nedergaard, 2004; Obara et al., 2008; Halassa and Haydon, 2010; Allaman et al., 2011; Clarke and Barres, 2013), and elimination of astrocytes exacerbates the inflammatory response and neuronal damage following a neurologic injury (Bush et al., 1999; Cui et al., 2001; Faulkner et al., 2004; Myer et al., 2006). Therefore, the multifaceted role of astrocytes in development, homeostasis, and injury does not allow full interpretation of the astrocyte histopathology. However, expression analyses revealed that markers of activated astrocytes were not elevated in the injured KI mice at the $9 \mathrm{~h}$ and $1 \mathrm{~d}$ p.i. time points. This raises the possibility that teasing out a functional role of altered astrocyte function may require more fine-tuned physiology-based endpoints to complement the histopathology.

In conclusion, the results reported here and the context of prior publications add to an increasing body of knowledge strongly indicating that TBI is a contributor to increased susceptibility to AD-relevant pathologies, including cognitive dysfunc- tion. The integrated use of an acute brain injury paradigm in a progressive neurodegenerative model is another variant of "priming" or two-hit injury paradigms, where one insult exacerbates the response to a second insult (Norden et al., 2014; Perry and Holmes, 2014). Neuroinflammation has clearly been implicated as a pathophysiology progression mechanism in such twohit paradigms, and MW151 intervention after the first insult provides pharmacological attenuation of the second insult response (Somera-Molina et al., 2009; Chrzaszcz et al., 2010). Therefore, our finding that MW151 treatment results in attenuation of the exaggerated response in the CHI-KI group extends the body of evidence that supports overproduction of cytokines and altered homeostatic glia functions as an important pathophysiological mechanism and promising therapeutic target.

\section{References}

Abner EL, Nelson PT, Schmitt FA, Browning SR, Fardo DW, Wan L, Jicha GA, Cooper GE, Smith CD, Caban-Holt AM, Van Eldik LJ, Kryscio RJ (2014) Self-reported head injury and risk of late-life impairment and AD pathology in an AD center cohort. Dement Geriatr Cogn Disord 37:294306. CrossRef Medline

Abrahamson EE, Ikonomovic MD, Ciallella JR, Hope CE, Paljug WR, Isanski BA, Flood DG, Clark RS, DeKosky ST (2006) Caspase inhibition therapy abolishes brain trauma-induced increases in Abeta peptide: implications for clinical outcome. Exp Neurol 197:437-450. CrossRef Medline

Abrahamson EE, Ikonomovic MD, Dixon CE, DeKosky ST (2009) Simvastatin therapy prevents brain trauma-induced increases in beta-amyloid peptide levels. Ann Neurol 66:407-414. CrossRef Medline

Alamed J, Wilcock DM, Diamond DM, Gordon MN, Morgan D (2006) Two-day radial-arm water maze learning and memory task: robust resolution of amyloid-related memory deficits in transgenic mice. Nat Protoc 1:1671-1679. CrossRef Medline

Allaman I, Bélanger M, Magistretti PJ (2011) Astrocyte-neuron metabolic relationships: for better and for worse. Trends Neurosci 34:76-87. CrossRef Medline

Bachstetter AD, Norris CM, Sompol P, Wilcock DM, Goulding D, Neltner JH, St Clair D, Watterson DM, Van Eldik LJ (2012) Early stage drug treatment that normalizes proinflammatory cytokine production attenuates synaptic dysfunction in a mouse model that exhibits age-dependent progression of Alzheimer's disease-related pathology. J Neurosci 32: 10201-10210. CrossRef Medline

Bachstetter AD, Webster SJ, Van Eldik LJ, Cambi F (2013a) Clinically relevant intronic splicing enhancer mutation in myelin proteolipid protein leads to progressive microglia and astrocyte activation in white and gray matter regions of the brain. J Neuroinflammation 10:146. CrossRef Medline

Bachstetter AD, Rowe RK, Kaneko M, Goulding D, Lifshitz J, Van Eldik LJ (2013b) The p38 $\alpha$ MAPK regulates microglial responsiveness to diffuse traumatic brain injury. J Neurosci 33:6143-6153. CrossRef Medline

Bachstetter AD, Webster SJ, Goulding D, Morton JE, Watterson DM, Van Eldik LJ (2015) Attenuation of traumatic brain injury-induced cognitive impairment in mice by targeting increased cytokine levels with a small molecule experimental therapeutic. J Neuroinflammation, in press.

Berard JL, Zarruk JG, Arbour N, Prat A, Yong VW, Jacques FH, Akira S, David $S$ (2012) Lipocalin 2 is a novel immune mediator of experimental autoimmune encephalomyelitis pathogenesis and is modulated in multiple sclerosis. Glia 60:1145-1159. CrossRef Medline

Brody DL, Holtzman DM (2006) Morris water maze search strategy analysis in PDAPP mice before and after experimental traumatic brain injury. Exp Neurol 197:330-340. CrossRef Medline

Brody DL, MacDonald C, Kessens CC, Yuede C, Parsadanian M, Spinner M, Kim E, Schwetye KE, Holtzman DM, Bayly PV (2007) Electromagnetic controlled cortical impact device for precise, graded experimental traumatic brain injury. J Neurotrauma 24:657-673. CrossRef Medline

Bush TG, Puvanachandra N, Horner CH, Polito A, Ostenfeld T, Svendsen CN, Mucke L, Johnson MH, Sofroniew MV (1999) Leukocyte infiltration, neuronal degeneration, and neurite outgrowth after ablation of scarforming, reactive astrocytes in adult transgenic mice. Neuron 23:297-308. CrossRef Medline

Butovsky O, Jedrychowski MP, Moore CS, Cialic R, Lanser AJ, Gabriely G, 
Koeglsperger T, Dake B, Wu PM, Doykan CE, Fanek Z, Liu L, Chen Z, Rothstein JD, Ransohoff RM, Gygi SP, Antel JP, Weiner HL (2014) Identification of a unique TGF-beta-dependent molecular and functional signature in microglia. Nat Neurosci 17:131-143. CrossRef Medline

Chiu IM, Morimoto ET, Goodarzi H, Liao JT, O'Keeffe S, Phatnani HP, Muratet M, Carroll MC, Levy S, Tavazoie S, Myers RM, Maniatis T (2013) A neurodegeneration-specific gene-expression signature of acutely isolated microglia from an amyotrophic lateral sclerosis mouse model. Cell Rep 4:385-401. CrossRef Medline

Chrzaszcz M, Venkatesan C, Dragisic T, Watterson DM, Wainwright MS (2010) Minozac treatment prevents increased seizure susceptibility in a mouse "two-hit" model of closed skull traumatic brain injury and electroconvulsive shock-induced seizures. J Neurotrauma 27:1283-1295. CrossRef Medline

Clarke LE, Barres BA (2013) Emerging roles of astrocytes in neural circuit development. Nat Rev Neurosci 14:311-321. CrossRef Medline

Craft JM, Watterson DM, Frautschy SA, Van Eldik LJ (2004a) Aminopyridazines inhibit beta-amyloid-induced glial activation and neuronal damage in vivo. Neurobiol Aging 25:1283-1292. CrossRef Medline

Craft JM, Van Eldik LJ, Zasadzki M, Hu W, Watterson DM (2004b) Aminopyridazines attenuate hippocampus-dependent behavioral deficits induced by human beta-amyloid in a murine model of neuroinflammation. J Mol Neurosci 24:115-122. CrossRef Medline

Craft JM, Watterson DM, Van Eldik LJ (2006) Human amyloid betainduced neuroinflammation is an early event in neurodegeneration. Glia 53:484-490. CrossRef Medline

Cui W, Allen ND, Skynner M, Gusterson B, Clark AJ (2001) Inducible ablation of astrocytes shows that these cells are required for neuronal survival in the adult brain. Glia 34:272-282. CrossRef Medline

Daigo K, Mantovani A, Bottazzi B (2014) The yin-yang of long pentraxin PTX3 in inflammation and immunity. Immunol Lett 161:38-43. CrossRef Medline

Deacon R (2012) Assessing burrowing, nest construction, and hoarding in mice. J Vis Exp 59:e2607. CrossRef Medline

Deacon RM (2006) Assessing nest building in mice. Nat Protoc 1:11171119. CrossRef Medline

Egashira Y, Hua Y, Keep RF, Xi G (2014) Acute white matter injury after experimental subarachnoid hemorrhage: potential role of lipocalin 2 . Stroke 45:2141-2143. CrossRef Medline

Faul M, Xu L, Wald MM, Coronado VG (2010) Traumatic brain injury in the United States: emergency department visits, hospitalizations, and deaths. Atlanta: Centers for Disease Control and Prevention, National Center for Injury Prevention and Control.

Faulkner JR, Herrmann JE, Woo MJ, Tansey KE, Doan NB, Sofroniew MV (2004) Reactive astrocytes protect tissue and preserve function after spinal cord injury. J Neurosci 24:2143-2155. CrossRef Medline

Flood DG, Reaume AG, Dorfman KS, Lin YG, Lang DM, Trusko SP, Savage MJ, Annaert WG, De Strooper B, Siman R, Scott RW (2002) FAD mutant PS- 1 gene-targeted mice: increased $\mathrm{A} \beta 42$ and $\mathrm{A} \beta$ deposition without APP overproduction. Neurobiol Aging 23:335-348. CrossRef Medline

Furman JL, Sama DM, Gant JC, Beckett TL, Murphy MP, Bachstetter AD, Van Eldik LJ, Norris CM (2012) Targeting astrocytes ameliorates neurologic changes in a mouse model of Alzheimer's disease. J Neurosci 32:16129-16140. CrossRef Medline

Gentleman SM, Nash MJ, Sweeting CJ, Graham DI, Roberts GW (1993) Beta-amyloid precursor protein (beta APP) as a marker for axonal injury after head injury. Neurosci Lett 160:139-144. CrossRef Medline

Gouras GK, Tampellini D, Takahashi RH, Capetillo-Zarate E (2010) Intraneuronal beta-amyloid accumulation and synapse pathology in Alzheimer's disease. Acta Neuropathol 119:523-541. CrossRef Medline

Halassa MM, Haydon PG (2010) Integrated brain circuits: astrocytic networks modulate neuronal activity and behavior. Annu Rev Physiol 72: 335-355. CrossRef Medline

Hickman SE, Kingery ND, Ohsumi TK, Borowsky ML, Wang LC, Means TK, El Khoury J (2013) The microglial sensome revealed by direct RNA sequencing. Nat Neurosci 16:1896-1905. CrossRef Medline

Hu W, Ralay Ranaivo H, Roy SM, Behanna HA, Wing LK, Munoz L, Guo L, Van Eldik LJ, Watterson DM (2007) Development of a novel therapeutic suppressor of brain proinflammatory cytokine up-regulation that attenuates synaptic dysfunction and behavioral deficits. Bioorg Med Chem Lett 17:414-418. CrossRef Medline

Ikonomovic MD, Uryu K, Abrahamson EE, Ciallella JR, Trojanowski JQ, Lee
VM, Clark RS, Marion DW, Wisniewski SR, DeKosky ST (2004) Alzheimer's pathology in human temporal cortex surgically excised after severe brain injury. Exp Neurol 190:192-203. CrossRef Medline

Jenrow KA, Brown SL, Lapanowski K, Naei H, Kolozsvary A, Kim JH (2013) Selective inhibition of microglia-mediated neuroinflammation mitigates radiation-induced cognitive impairment. Radiat Res 179:549-556. CrossRef Medline

Jin M, Kim JH, Jang E, Lee YM, Soo Han H, Woo DK, Park DH, Kook H, Suk K (2014) Lipocalin-2 deficiency attenuates neuroinflammation and brain injury after transient middle cerebral artery occlusion in mice. J Cereb Blood Flow Metab 34:1306-1314. CrossRef Medline

Johnson VE, Stewart W, Smith DH (2010) Traumatic brain injury and amyloid- $\beta$ pathology: a link to Alzheimer's disease? Nat Rev Neurosci 11:361-370. CrossRef Medline

Karpus WJ, Reynolds N, Behanna HA, Van Eldik LJ, Watterson DM (2008) Inhibition of experimental autoimmune encephalomyelitis by a novel small molecular weight proinflammatory cytokine suppressing drug. J Neuroimmunol 203:73-78. CrossRef Medline

Kimelberg HK (1992) Astrocytic edema in CNS trauma. J Neurotrauma 9 [Suppl 1]:S71-S81.

Kimelberg HK, Rutledge E, Goderie S, Charniga C (1995) Astrocytic swelling due to hypotonic or high $\mathrm{K}^{+}$medium causes inhibition of glutamate and aspartate uptake and increases their release. J Cereb Blood Flow Metab 15:409-416. CrossRef Medline

Kumar A, Loane DJ (2012) Neuroinflammation after traumatic brain injury: opportunities for therapeutic intervention. Brain Behav Immun 26: 1191-1201. CrossRef Medline

Laird MD, Vender JR, Dhandapani KM (2008) Opposing roles for reactive astrocytes following traumatic brain injury. Neurosignals 16:154-164. CrossRef Medline

Laskowitz DT, Song P, Wang H, Mace B, Sullivan PM, Vitek MP, Dawson HN (2010) Traumatic brain injury exacerbates neurodegenerative pathology: improvement with an apolipoprotein E-based therapeutic. J Neurotrauma 27:1983-1995. CrossRef Medline

Lloyd E, Somera-Molina K, Van Eldik LJ, Watterson DM, Wainwright MS (2008) Suppression of acute proinflammatory cytokine and chemokine upregulation by post-injury administration of a novel small molecule improves long-term neurologic outcome in a mouse model of traumatic brain injury. J Neuroinflammation 5:28. CrossRef Medline

Loane DJ, Byrnes KR (2010) Role of microglia in neurotrauma. Neurotherapeutics 7:366-377. CrossRef Medline

Loane DJ, Pocivavsek A, Moussa CE, Thompson R, Matsuoka Y, Faden AI, Rebeck GW, Burns MP (2009) Amyloid precursor protein secretases as therapeutic targets for traumatic brain injury. Nat Med 15:377-379. CrossRef Medline

Lynch JR, Wang H, Mace B, Leinenweber S, Warner DS, Bennett ER, Vitek MP, McKenna S, Laskowitz DT (2005) A novel therapeutic derived from apolipoprotein $\mathrm{E}$ reduces brain inflammation and improves outcome after closed head injury. Exp Neurol 192:109-116. CrossRef Medline

Macauley SL, Wong AM, Shyng C, Augner DP, Dearborn JT, Pearse Y, Roberts MS, Fowler SC, Cooper JD, Watterson DM, Sands MS (2014) An anti-neuroinflammatory that targets dysregulated glia enhances the efficacy of CNS-directed gene therapy in murine infantile neuronal ceroid lipofuscinosis. J Neurosci 34:13077-13082. CrossRef Medline

McCoy MK, Tansey MG (2008) TNF signaling inhibition in the CNS: implications for normal brain function and neurodegenerative disease. J Neuroinflammation 5:45. CrossRef Medline

Mizutani M, Pino PA, Saederup N, Charo IF, Ransohoff RM, Cardona AE (2012) The fractalkine receptor but not CCR2 is present on microglia from embryonic development throughout adulthood. J Immunol 188: 29-36. CrossRef Medline

Morganti-Kossmann MC, Satgunaseelan L, Bye N, Kossmann T (2007) Modulation of immune response by head injury. Injury 38:1392-1400. CrossRef Medline

Mosher KI, Wyss-Coray T (2014) Microglial dysfunction in brain aging and Alzheimer's disease. Biochem Pharmacol 88:594-604. CrossRef Medline

Murphy MP, Beckett TL, Ding Q, Patel E, Markesbery WR, St Clair DK, LeVine H 3rd, Keller JN (2007) A $\beta$ solubility and deposition during AD progression and in APPxPS-1 knock-in mice. Neurobiol Dis 27:301-311. CrossRef Medline

Myer DJ, Gurkoff GG, Lee SM, Hovda DA, Sofroniew MV (2006) Essential 
protective roles of reactive astrocytes in traumatic brain injury. Brain 129:2761-2772. CrossRef Medline

Nakagawa Y, Nakamura M, McIntosh TK, Rodriguez A, Berlin JA, Smith DH, Saatman KE, Raghupathi R, Clemens J, Saido TC, Schmidt ML, Lee VM, Trojanowski JQ (1999) Traumatic brain injury in young, amyloid-beta peptide overexpressing transgenic mice induces marked ipsilateral hippocampal atrophy and diminished Abeta deposition during aging. J Comp Neurol 411:390-398. CrossRef Medline

Nakagawa Y, Reed L, Nakamura M, McIntosh TK, Smith DH, Saatman KE, Raghupathi R, Clemens J, Saido TC, Lee VM, Trojanowski JQ (2000) Brain trauma in aged transgenic mice induces regression of established abeta deposits. Exp Neurol 163:244-252. CrossRef Medline

Norden DM, Muccigrosso MM, Godbout JP (2014) Microglial priming and enhanced reactivity to secondary insult in aging, and traumatic CNS injury, and neurodegenerative disease. Neuropharmacology. Advance online publication. Retrieved Nov. 13, 2014. doi: 10.1016/j.neuropharm.2014.10.028. CrossRef Medline

Obara M, Szeliga M, Albrecht J (2008) Regulation of pH in the mammalian central nervous system under normal and pathological conditions: facts and hypotheses. Neurochem Int 52:905-919. CrossRef Medline

Perry VH, Holmes C (2014) Microglial priming in neurodegenerative disease. Nat Rev Neurol 10:217-224. CrossRef Medline

Ramlackhansingh AF, Brooks DJ, Greenwood RJ, Bose SK, Turkheimer FE, Kinnunen KM, Gentleman S, Heckemann RA, Gunanayagam K, Gelosa G, Sharp DJ (2011) Inflammation after trauma: microglial activation and traumatic brain injury. Ann Neurol 70:374-383. CrossRef Medline

Rathore KI, Berard JL, Redensek A, Chierzi S, Lopez-Vales R, Santos M, Akira S, David S (2011) Lipocalin 2 plays an immunomodulatory role and has detrimental effects after spinal cord injury. J Neurosci 31:13412-13419. CrossRef Medline

Reaume AG, Howland DS, Trusko SP, Savage MJ, Lang DM, Greenberg BD, Siman R, Scott RW (1996) Enhanced amyloidogenic processing of the $\beta$-amyloid precursor protein in gene-targeted mice bearing the Swedish familial Alzheimer's disease mutations and a "humanized" A $\beta$ sequence. J Biol Chem 271:23380-23388. CrossRef Medline

Roberts GW, Gentleman SM, Lynch A, Murray L, Landon M, Graham DI (1994) Beta amyloid protein deposition in the brain after severe head injury: implications for the pathogenesis of Alzheimer's disease. J Neurol Neurosurg Psychiatry 57:419-425. CrossRef Medline

Rodriguez-Grande B, Swana M, Nguyen L, Englezou P, Maysami S, Allan SM, Rothwell NJ, Garlanda C, Denes A, Pinteaux E (2014) The acute-phase protein PTX3 is an essential mediator of glial scar formation and resolution of brain edema after ischemic injury. J Cereb Blood Flow Metab 34:480-488. CrossRef Medline

Sama DM, Norris CM (2013) Calcium dysregulation and neuroinflammation: discrete and integrated mechanisms for age-related synaptic dysfunction. Ageing Res Rev 12:982-995. CrossRef Medline

Saraiva M, O'Garra A (2010) The regulation of IL-10 production by immune cells. Nat Rev Immunol 10:170-181. CrossRef Medline

Schousboe A, Sarup A, Bak LK, Waagepetersen HS, Larsson OM (2004) Role of astrocytic transport processes in glutamatergic and GABAergic neurotransmission. Neurochem Int 45:521-527. CrossRef Medline

Schwetye KE, Cirrito JR, Esparza TJ, MacDonald CL, Holtzman DM, Brody DL (2010) Traumatic brain injury reduces soluble extracellular amyloid-beta in mice: a methodologically novel combined microdialysiscontrolled cortical impact study. Neurobiol Dis 40:555-564. CrossRef Medline

Sherriff FE, Bridges LR, Sivaloganathan S (1994) Early detection of axonal injury after human head trauma using immunocytochemistry for betaamyloid precursor protein. Acta Neuropathol 87:55-62. CrossRef Medline

Shively S, Scher AI, Perl DP, Diaz-Arrastia R (2012) Dementia resulting from traumatic brain injury: what is the pathology? Arch Neurol 69:12451251. CrossRef Medline

Siman R, Reaume AG, Savage MJ, Trusko S, Lin YG, Scott RW, Flood DG (2000) Presenilin-1 P264L knock-in mutation: differential effects on abeta production, amyloid deposition, and neuronal vulnerability. J Neurosci 20:8717-8726. Medline

Simard M, Nedergaard M (2004) The neurobiology of glia in the context of water and ion homeostasis. Neuroscience 129:877-896. CrossRef Medline

Sofroniew MV (2014) Multiple roles for astrocytes as effectors of cytokines and inflammatory mediators. Neuroscientist 20:160-172. CrossRef Medline

Somera-Molina KC, Robin B, Somera CA, Anderson C, Stine C, Koh S, Behanna HA, Van Eldik LJ, Watterson DM, Wainwright MS (2007) Glial activation links early-life seizures and long-term neurologic dysfunction: evidence using a small molecule inhibitor of proinflammatory cytokine upregulation. Epilepsia 48:1785-1800. CrossRef Medline

Somera-Molina KC, Nair S, Van Eldik LJ, Watterson DM, Wainwright MS (2009) Enhanced microglial activation and proinflammatory cytokine upregulation are linked to increased susceptibility to seizures and neurologic injury in a 'two-hit' seizure model. Brain Res 1282:162-172. CrossRef Medline

Tajiri N, Kellogg SL, Shimizu T, Arendash GW, Borlongan CV (2013) Traumatic brain injury precipitates cognitive impairment and extracellular $\mathrm{A} \beta$ aggregation in Alzheimer's disease transgenic mice. PLoS One 8:e78851. CrossRef Medline

Tran HT, LaFerla FM, Holtzman DM, Brody DL (2011) Controlled cortical impact traumatic brain injury in $3 \times \mathrm{Tg}-\mathrm{AD}$ mice causes acute intra-axonal amyloid-beta accumulation and independently accelerates the development of tau abnormalities. J Neurosci 31:9513-9525. CrossRef Medline

Ubogu EE, Cossoy MB, Ransohoff RM (2006) The expression and function of chemokines involved in CNS inflammation. Trends Pharmacol Sci 27:48-55. CrossRef Medline

Uryu K, Laurer H, McIntosh T, Praticò D, Martinez D, Leight S, Lee VM, Trojanowski JQ (2002) Repetitive mild brain trauma accelerates Abeta deposition, lipid peroxidation, and cognitive impairment in a transgenic mouse model of Alzheimer amyloidosis. J Neurosci 22:446-454. Medline

Van Eldik LJ, Thompson WL, Ralay Ranaivo H, Behanna HA, Martin Watterson D (2007) Glia proinflammatory cytokine upregulation as a therapeutic target for neurodegenerative diseases: function-based and target-based discovery approaches. Int Rev Neurobiol 82:277-296. CrossRef Medline

Verkhratsky A, Sofroniew MV, Messing A, deLanerolle NC, Rempe D, Rodriguez JJ, Nedergaard M (2012) Neurological diseases as primary gliopathies: a reassessment of neurocentrism. ASN Neuro 4:art:e00082. CrossRef Medline

Viola A, Luster AD (2008) Chemokines and their receptors: drug targets in immunity and inflammation. Annu Rev Pharmacol Toxicol 48:171-197. CrossRef Medline

Washington PM, Morffy N, Parsadanian M, Zapple DN, Burns MP (2014) Experimental traumatic brain injury induces rapid aggregation and oligomerization of amyloid-beta in an Alzheimer's disease mouse model. J Neurotrauma 31:125-134. CrossRef Medline

Webster SJ, Bachstetter AD, Van Eldik LJ (2013) Comprehensive behavioral characterization of an APP/PS- 1 double knock-in mouse model of Alzheimer's disease. Alzheimers Res Ther 5:28. CrossRef Medline

Woodcock T, Morganti-Kossmann MC (2013) The role of markers of inflammation in traumatic brain injury. Front Neurol 4:18. CrossRef Medline

Wyss-Coray T, Rogers J (2012) Inflammation in Alzheimer disease: a brief review of the basic science and clinical literature. Cold Spring Harb Perspect Med 2:a006346. CrossRef Medline

Xiong Y, Mahmood A, Chopp M (2013) Animal models of traumatic brain injury. Nat Rev Neurosci 14:128-142. CrossRef Medline

Zamanian JL, Xu L, Foo LC, Nouri N, Zhou L, Giffard RG, Barres BA (2012) Genomic analysis of reactive astrogliosis. J Neurosci 32:6391-6410. CrossRef Medline

Zhang C, McNeil E, Dressler L, Siman R (2007) Long-lasting impairment in hippocampal neurogenesis associated with amyloid deposition in a knock-in mouse model of familial Alzheimer's disease. Exp Neurol 204: 77-87. CrossRef Medline 